\title{
ipen
}

INSTITUTO DE PESQUISAS ENERGÉTICAS E NUCLEARES

AUTARQUIA ASSOCIADA À UNIVERSIDADE DE SÃO PAULO

\section{DESENVOLVIMENTO DE FONTES RADIOATIVAS SELADAS IMOBILIZADAS EM RESINA EPÓXI PARA VERIFICAÇÃO DE DETECTORES UTILIZADOS EM MEDICINA NUCLEAR}

Rodrigo Tiezzi

Dissertação apresentada como parte dos requisitos para obtenção do Grau de Mestre em Ciências na Área de Tecnologia Nuclear - Aplicações.

Orientadora:

Dra. Maria Elisa Chuery Martins Rostelato

SÃO PAULO

2016 
Dedico esse trabalho aos meus pais, às minhas irmãs e sobrinhas 


\section{AGRADECIMENTOS}

À minha orientadora, Dra. Maria Elisa Chuery Martins Rostelato, por confiar no meu trabalho, pelo desafio dado, pela orientação e amizade.

À minha mãe Maria Aparecida Tiezzi e ao meu pai Roberto Tiezzi pelo incentivo constante, por todo amor, esforço, compreensão incansável ao longo de toda a minha vida. Também por toda educação que na sua forma mais simples de transmitir, me levou a ser o eu de hoje.

Ao apoio excepcional do Me. Hélio Rissei Nagatomi. Pelas conversas sempre produtivas e por tudo que me ensinou para o desenvolvimento deste trabalho.

Ao Dr. Carlos Alberto Zeituni pelas valiosas discussões principalmente no início do trabalho e que propiciaram um excelente direcionamento do projeto.

Ao Centro de Tecnologia das Radiações (CTR) e ao Instituto de Pesquisas Energéticas e Nucleares (IPEN) pela oportunidade.

Especial à Comissão Nacional de Energia Nuclear (CNEN), que desempenhou papel fundamental na expansão e consolidação da minha pós-graduação concedendo a bolsa de estudos que me permitiu a execução deste trabalho.

À Dra. Luci Diva Brocardo Machado pela concessão de seu laboratório e auxílio e orientação na execução das análises térmicas.

Ao Djalma Batista Dias pela prontidão na ajuda com as análises térmicas e mecânicas.

Ao amigo Osvaldo Luiz da Costa pelos ensinamentos e por permitir a ajuda no acompanhamento do seu trabalho de doutorado.

Aos amigos do grupo pelas conversas e auxílio nas atividades, em especial ao Marcos Antônio Gimenez Benega, Carla Daruich de Souza, Daiani Cristini Barbosa de Souza, Bruna Teiga Rodrigues, Fernado Peleias e Anderson Sorgatti.

À equipe de proteção radiológica por todo companheirismo em todos os monitoramentos do laboratório.

À equipe do Irradiador Multipropósito de Cobalto 60 - CTR, pela irradiação do material utilizado nesse trabalho. 


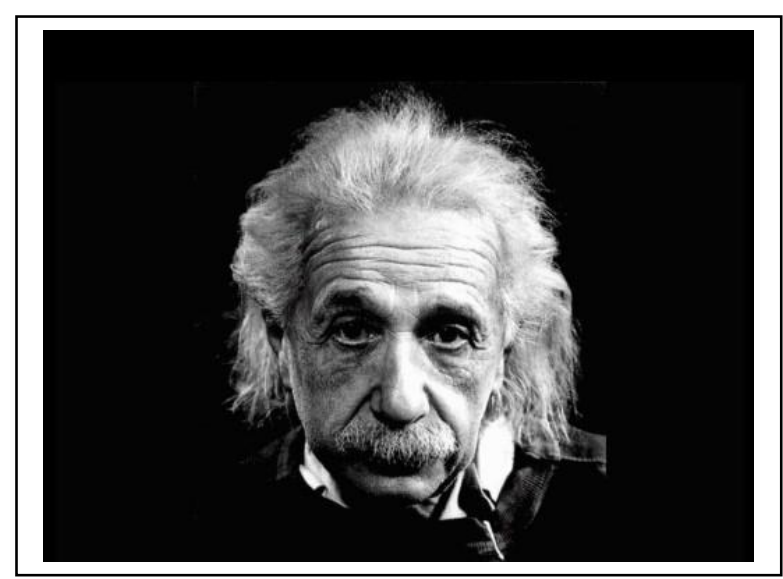

"A mente que se abre a uma nova ideia jamais voltará ao tamanho normal." 


\section{DESENVOLVIMENTO DE FONTES RADIOATIVAS SELADAS \\ IMOBILIZADAS EM RESINA EPÓXI PARA VERIFICAÇÃO DE \\ DETECTORES UTILIZADOS EM MEDICINA NUCLEAR}

\section{Rodrigo Tiezzi}

\section{RESUMO}

As fontes radioativas seladas são usadas na verificação de detectores de câmara de ionização, os quais medem a atividade dos radioisótopos usados nas mais diversas áreas, como na Medicina Nuclear. A medida da atividade dos radioisótopos deve ser feita com exatidão, pois será administrada em um paciente. Para garantir o adequado funcionamento dos detectores de câmara de ionização, são estipulados ensaios normatizados pela Agência Internacional de Energia Atômica (IAEA) e a Comissão Nacional de Energia Nuclear (CNEN) utilizando-se fontes radioativas seladas de Bário133, Césio-137 e Cobalto-57. Os testes avaliam a exatidão, precisão, reprodutibilidade e linearidade da resposta do equipamento. $\mathrm{O}$ foco deste trabalho foi o estudo e o desenvolvimento dessas fontes radioativas padrão de Bário-133, Césio-137 e Cobalto57, utilizando um polímero, no caso resina epóxi comerciais do tipo éter diglicidílico do bisfenol A e um agente de cura a base de poliamina modificada da dietilenotriamina ,para imobilizar o material radioativo. A matriz polimérica apresenta a função primordial de fixar e imobilizar o conteúdo radioativo não permitindo seu vazamento dentro dos limites técnicos exigidos pelas normas de proteção radiológica no quesito de características de uma fonte selada e, adicionalmente, ter a capacidade de reter a emanação de quaisquer gases que venham a se formar durante o processo de fabricação e do período de vida útil deste artefato. O processo de manufatura de uma fonte selada padrão consiste no envasamento, em um frasco de geometria padronizada, de uma quantidade, em volume fixo, de uma matriz polimérica no interior da qual é adicionada e dispersada homogeneamente uma quantidade precisa e exata em atividade de um material radioativo padrão. Nesse sentido, realizou-se um estudo para a escolha da resina epóxi, analisando suas características e propriedades. Foram realizados estudos e testes, verificando a máxima miscibilidade da resina com a água (solução ácida, simulando as condições da solução radiativa), perdas de propriedades mecânicas e térmicas, bem como o controle de dose radioativa para a completa cura (irradiadores de 
cobalto).Foram produzidas fontes de césio-137 e bário-133, realizou-se testes para determinação do grau de homogeneidade na dispersão do material radioativo na matriz e testes de imersão das fontes seladas produzidas para verificar a estanqueidade do sistema desenvolvido, obtendo um resultado satisfatório de acordo com as normas. Analisando todos os resultados obtidos, as fontes seladas podem ser confeccionadas em matriz epóxi DGEBA e endurecedor poliamínico DETA modificado, desde que a quantidade de material radioativo, na forma de solução ácida, adicionado à composição não ultrapasse um teor de $20 \%$. A cura da resina epóxi pode ser melhorada em relação a ambiente, com uso da irradiação desde que seja exposta a uma dose ao redor de 33 kGy durante a cura. Nos testes de estanqueidade, verificou-se que as fontes são estanques, as medições da atividade da água utilizada nos testes mostraram um valor inferior a 185 $\mathrm{Bq}$ (de acordo com a International Standard Organization- Radiation protection - sealed radioactive sources - ISO 9978), comprovando a eficiência da resina epóxi como material para selar o material radioativo. Tendo a finalidade de criar uma tecnologia nacional capaz de suprir a demanda deste produto no mercado interno e atingir excelência em qualidade através da acreditação e certificação do produto junto aos órgãos competentes. 


\title{
DEVELOPMENT OF SEALED RADIOACTIVE SOURCES IMMOBILIZED IN EPOXY RESIN FOR VERIFICATION OF DETECTORS USED IN NUCLEAR MEDICINE
}

\section{Rodrigo Tiezzi}

\begin{abstract}
The radioactive sealed sources are used in verification ionization chamber detectors, which measure the activity of radioisotopes used in several areas, such as in nuclear medicine. The measurement of the activity of radioisotopes must be made with accuracy, because it is administered to a patient. To ensure the proper functioning of the ionization chamber detectors, standardized tests are set by the International Atomic Energy Agency (IAEA) and the National Nuclear Energy Commission using sealed radioactive sources of Barium-133, Cesium-137 and Cobalt-57. The tests assess the accuracy, precision, reproducibility and linearity of response of the equipment. The focus of this work was the study and the development of these radioactive sources with standard Barium-133 and Cesium-137, using a polymer, in case commercial epoxy resin of diglycidyl ether of bisphenol A (DGEBA) and a curing agent based on modified polyamine diethylenetriamine (DETA), to immobilize the radioactive material. The polymeric matrix has the main function of fix and immobilize the radioactive contents not allowing them to leak within the technical limits required by the standards of radiological protection in the category of characteristics of a sealed source and additionally have the ability to retain the emanation of any gases that may be formed during the manufacture process and the useful life of this artifact. The manufacturing process of a sealed source standard consists of the potting, into bottle standardized geometry, in fixed volume of a quantity of a polymeric matrix within which is added and dispersed homogeneously to need and exact amount in activity of the radioactive materials standards. Accordingly, a study was conducted for the choice of epoxy resin, analyzing its characteristics and properties. Studies and tests were performed, examining the maximum miscibility of the resin with the water (acidic solution, simulating the conditions of radioactive solution), loss of mechanical and thermal properties, as well as the radioactive dose control for complete curing (cobalt irradiators). For this work was produced a sources of barium-133 and cesium -137,tests
\end{abstract}


were conducted to determination the degree of homogeneity in the dispersion of the radioactive material in the matrix and immersion tests of sealed sources produced to verify the leakage (ISO 9978) of the developed system, occurring obtaining a satisfactory result. With the purpose of creating a national technology able to meet the demand of this product in the domestic market and achieve excellence in quality through accreditation and certification of the product by the appropriate bodies. 
Página

1. INTRODUÇÃ

1.1 Radioatividade e Aplicações das Fontes Radioativas Seladas ......................... 15

1.2 A Importância das fontes radioativas seladas para verificação de detectores na Medicina Nuclear .................................................................... 17

1.3 Fontes Radioativas Seladas Imobilizadas em Resina Epóxi ............................ 19

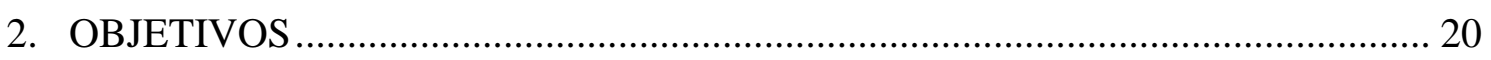

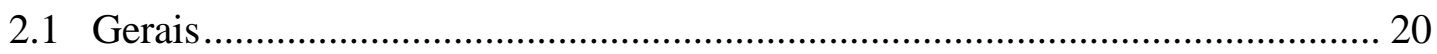

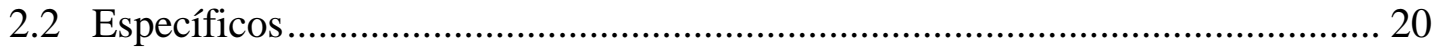

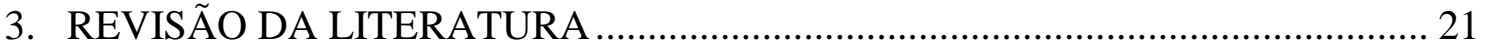

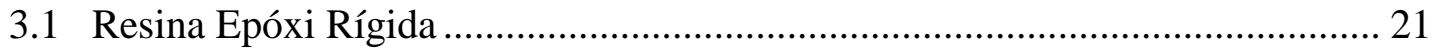

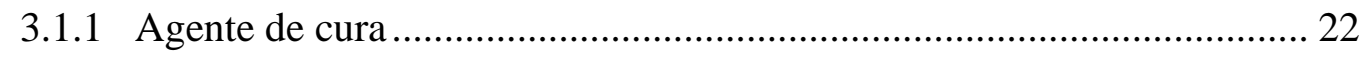

3.1.2 Características da Resina Epóxi Curada e Miscibilidade com a água.... 23

3.1.3 Irradiação de polímeros - Melhoria das propriedades mecânicas .......... 24

3.2 Fontes Radioativas Seladas Imobilizadas em Resina Epóxi ............................ 25

3.2.1 Fontes Radioativas Seladas de Verificação de Detectores usadas no

Serviço de Medicina Nuclear. ....................................................................... 26

3.2.2 Descrição de um Detector de Câmara de Ionização tipo poço usado no

Serviço de Medicina Nuclear ..................................................................... 27

3.3 Classificação e estanqueidade de fontes radioativas seladas- Normas

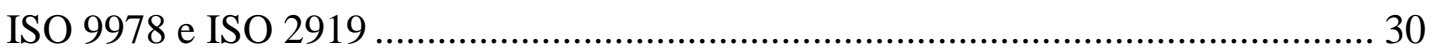

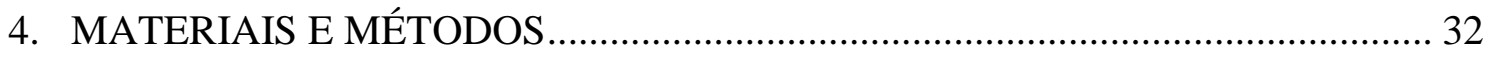

4.1 Escolha da resina epóxi rígida comercial mais adequada para o

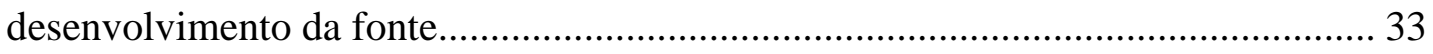

4.2 Estudo das propriedades da resina epóxi rígida escolhida. ............................... 33

4.2.1 A capacidade de miscibilidade da resina com água .............................. 35

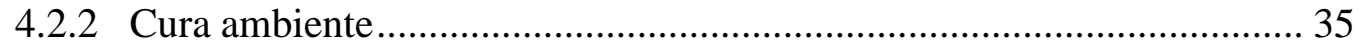

4.2.3 Ensaios de tração e compressão.......................................................... 35

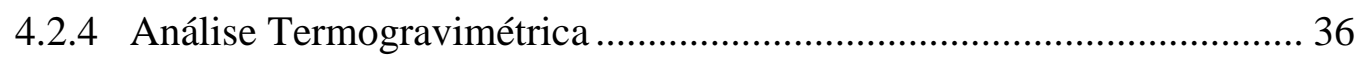

4.2.5 Estudo da aceleração do processo de cura por radiação gama e teste mecânicos de tração ....................................................................................... 37

4.2.6 Análise termogravimétrica das amostras irradiadas ............................ 38 
4.3 Produção das fontes de calibração

4.4 Execução dos testes de estanqueidade normalizados pela norma "International

Standard Organization Radiation protection - leakage test methods" ISO 9978 ..... 42

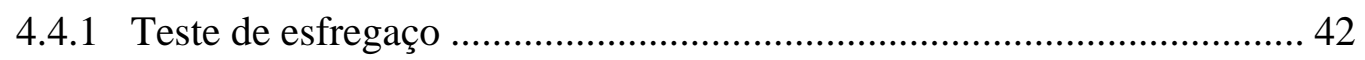

4.4.2 Teste de imersão à temperatura ambiente e teste de imersão a líquido

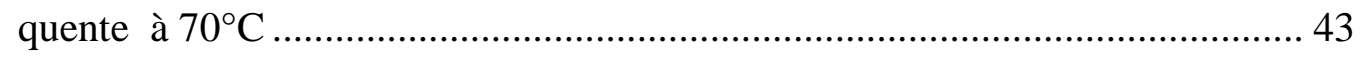

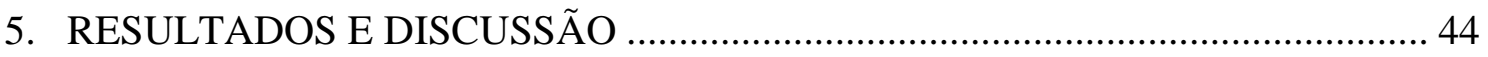

5.1 Resultados dos estudos da exatidão e precisão dos ativimetros disponíveis no

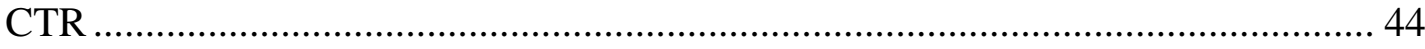

5.2 Resultados do estudo das propriedades da resina epóxi curada. ....................... 45

5.2.1 Capacidade de cura ambiente da miscibilidade da resina com água ...... 45

5.2.2 Resultados dos ensaios de tração........................................................ 46

5.2.3 Resultados dos ensaios de compressão.................................................. 48

5.2.4 Resultados do estudo da aceleração do processo de cura por radiação gama e Teste mecânicos e térmicos da resina curada ...................................... 50

5.2.5 Resultados da Análise Termogravimétrica........................................... 52

5.2.6 Resultado da análise termogravimétrica das amostras irradiadas .......... 54

5.3 Resultados da homogeneidade das fontes produzidas de bário e césio seladas

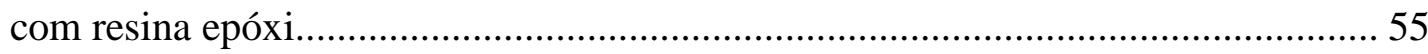

5.3.1 Teste da distribuição da resina mais endurecedor ................................ 55

5.3.2 Medição da atividade das fontes de ${ }^{137}$ Césio e ${ }^{133}$ Bário

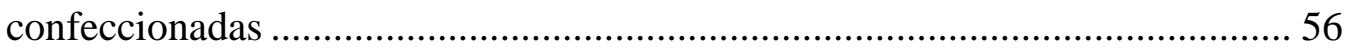

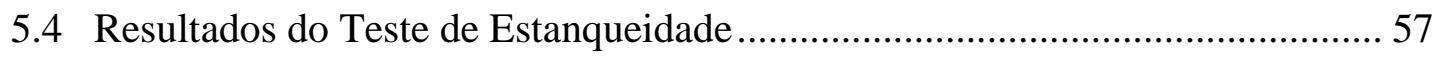

5.4.1 Resultado - Teste de esfregaço ........................................................... 57

5.4.2 Resultado - Teste de imersão à temperatura ambiente e teste de

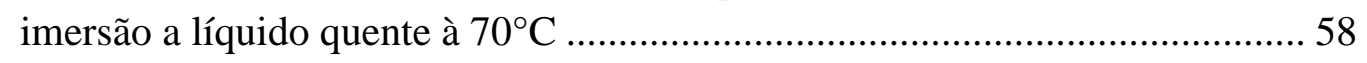

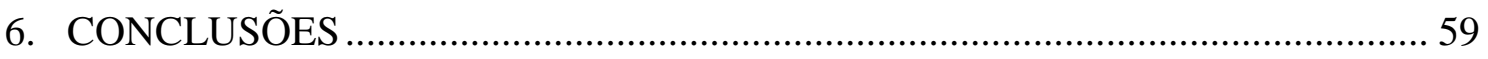

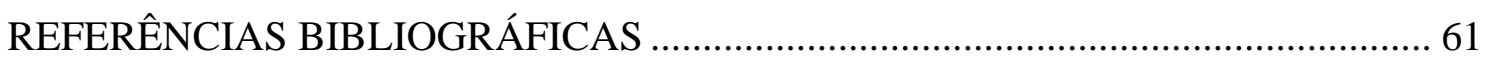




\section{LISTA DE TABELAS}

Página

TABELA 1 - Testes obrigatórios para medidores de atividade (curiômetros) em medicina nuclear ${ }^{(24)}$

TABELA 2 - Atividades e meias vidas das fontes radioativas sólidas importadas, que são produzidas no laboratório alemão de fontes radioativas seladas da Eckert \& Ziegler Isotope Products $(\mathrm{E} \& Z)^{(29,30)}$

TABELA 3 - Seleção dos métodos de testes de vazamento ${ }^{(32)}$....................................... 31

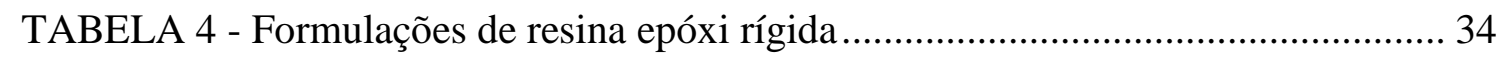

TABELA 5 - Quantidades de material radioativo utilizado para a confecção de fontes e medição da atividade 40

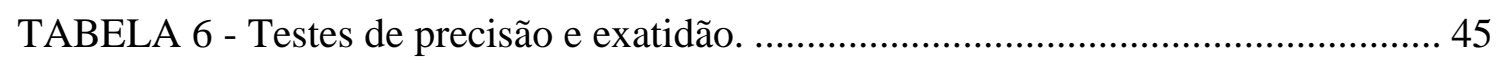

TABELA 7 - Tempo de cura ambiente das formulações. ........................................... 45

TABELA 8 - Medida das atividades das fontes em 3 modelos de detectores

Capintec.....

TABELA 9 - Medida da atividade do papel utilizado no esfregaço das fontes. 58

TABELA 10 - Medidas da Atividade da água à temperatura ambiente, antes e após a imersão das fontes 58

TABELA 11 - Medidas da Atividade da água à $70^{\circ} \mathrm{C}$, antes e após a imersão das fontes 


\section{LISTA DE FIGURAS}

Página

FIGURA 1 - Detectores modelos CRC-15W, CRC-15R e CRC BT. 18

FIGURA 2 - Fontes radioativas seladas com resina epóxi produzidas no CTR-IPEN .. 20 FIGURA 3 - Molécula de resina epoxídica (diglicidil éter do bisfenol A - DGEBA) $)^{(33)}$ 22

FIGURA 4 - Esquema do processo de reação da cura do epóxi ${ }^{(35)}$. 23

FIGURA 5 - Esquema de uma fonte padrão Eckert \& Ziegler ${ }^{(43)}$ 27

FIGURA 6 - Esquema de um detector câmara de ionização ${ }^{(43)}$ 29

FIGURA 7 - Esquema da câmara de ionização do detector ${ }^{(43)}$. 30

FIGURA 8 - Formas de silicone, utilizadas para confecções dos corpos de prova de resina epóxi, para os testes de tração e compressão respectivamente.

FIGURA 9 - Medidor de tração Instron 5567 com corpo de prova de resina epóxi rígida

FIGURA 10 - Equipamento para análise termogravimétrica (TG) modelo SDT Q600

FIGURA 11 - Irradiador Multipropósito de Cobalto -60 do IPEN e posição em que as amostras foram irradiadas. 38

FIGURA 12 - Corpos de prova irradiados com as seguintes doses 0, 20, 40, 60, 100, 150 e $200 \mathrm{kGy}$. 38

FIGURA 13 - Ampola da solução radioativa de bário-133 importada da empresa Eckert \& Ziegler . 39

FIGURA 14 - Fontes seladas de Césio-137 e Bário-133, produzidas neste trabalho..... 39

FIGURA 15 - Etapas da confecção da fonte de ${ }^{133} \mathrm{Ba}$ imobilizada em resina epóxi...... 41

FIGURA 16 - Fonte produzida de Cs -137 imobilizada em resina epóxi ...................... 42

FIGURA 17 - Esfregaço com papel absorvente da fonte de Césio-137 ......................... 42

FIGURA 18 - Detector de iodeto de sódio modelo CRC-15W ...................................... 43

FIGURA 19 - Fonte imersa em água destilada para os testes de estanqueidade ............ 44

FIGURA 20 - Copos de prova de resina epóxi com diferentes concentrações de solução radioativa e teste de tração realizado em Instron.......................................................... 46

FIGURA 21 - Corpos de Prova após teste de tração...................................................... 47

FIGURA 22 - Curva da Tração de Ruptura em função da porcentagem de água .......... 47

FIGURA 23 - Curva elongação em função da porcentagem de água. .......................... 48

FIGURA 24 - Copos de prova de resina epóxi com diferentes concentrações de solução radioativa e teste de compressão realizado em Instron 48 
FIGURA 25 - Corpo de prova após ensaio de compressão.

FIGURA 26 - Curva da resistência à Compressão em função da porcentagem de água.

FIGURA 27 - Curva de Tração de Ruptura em função da dose recebida.

FIGURA 28 - Curva de resistência à compressão em função da dose recebida 51

FIGURA 29 - Densidade da resina em função da dose recebida

FIGURA 30 - Perda de massa em função da temperatura, para amostras de diferentes porcentagens de solução ácida $(0-20 \%)$ em peso da resina mais endurecedor

FIGURA 31 - Perda de massa da resina pura mais endurecedor em função da temperatura sem adição da solução ácida.

FIGURA 32 - Curvas termogravimétricas das amostras sem irradiação e das irradiadas com as doses de $20 \mathrm{kGy}$ e $40 \mathrm{kGy}$ 55

FIGURA 33 - Verificação da homogeneidade da resina no frasco da fonte. 56

FIGURA 34 - Fonte de ${ }^{137}$ Cs e fonte de ${ }^{133}$ Ba confeccionadas 56 


\section{INTRODUÇÃO}

A medicina nuclear é uma especialidade multidisciplinar que combina Física, Matemática, Química, Computação e Medicina na utilização de pequenas quantidades de materiais radioativos, ou radiofármacos, para diagnosticar e tratar doenças ${ }^{(1)}$.

Segundo dados da revista Scientific American Brasil, em 2002 mais de dois milhões de pessoas foram beneficiadas com uso de radiofármacos, o que evidencia a necessidade de um controle de qualidade rigoroso, nas avaliações dos equipamentos utilizados ${ }^{(2)}$. Para que os pacientes não venham a receber doses menores do que as necessárias e tenham que fazer um novo exame.

Em janeiro de 2010 havia 335 clínicas de medicina nuclear cadastradas junto a $\mathrm{CNEN}^{(3)}$, sendo que este número foi ultrapassado em dezembro de 2014 chegando a 432 clínicas cadastradas ${ }^{(4)}$.

A necessidade de um detector confiável, com alta estabilidade a curto e longo prazos e medidas sob uma larga faixa de atividade em um Serviço de Medicina Nuclear já vem sendo reconhecida há muito tempo ${ }^{(5)}$.

Os sistemas que utilizam câmaras de ionização são os instrumentos preferidos para medir a atividade de radionuclídeos empregados em Medicina Nuclear ${ }^{(1)}$.

Uma vez que um detector de câmara de ionização é utilizado para determinar a atividade do radionuclídeo administrado ao paciente num exame específico ou num procedimento terapêutico, é de vital importância que esteja em perfeito funcionamento e seja regularmente calibrado num centro de calibração credenciado pelas autoridades do País. Isto só pode ser assegurado se determinados procedimentos de garantia de qualidade forem seguidos. Alguns testes de controle de qualidade devem ser realizados diariamente, outros trimestralmente e outros semestralmente ou anualmente, testandose, por exemplo, a exatidão e a precisão, a reprodutibilidade e a linearidade de resposta $(6,7)$.

Os primeiros calibradores de dose para aplicações de Medicina Nuclear foram descritos e testados por SINCLAIR \& NEWBERY ${ }^{(8)}$, BULLEN ${ }^{(9)}$ e SINCLAIR et 
al. ${ }^{(10)}$. Eles apresentaram fatores de calibração para soluções de ${ }^{131} \mathrm{I},{ }^{198} \mathrm{Au},{ }^{59} \mathrm{Fe},{ }^{60} \mathrm{Co}$ e outros radionuclídeos ${ }^{(1)}$.

São apresentados por vários autores detalhes sobre as condições de medidas, tais como as variações encontradas nas medidas de atividade em função das dimensões e do material da amostra e de sua posição no poço da câmara ${ }^{(11,12)}$ e devido às impurezas radionuclídicas encontradas nos radiofármacos ${ }^{(13,14)}$.

As fontes radioativas seladas, com radionuclídeos de energias variadas (alta, média e baixa energias) são de extrema importância para as verificações desses detectores utilizados na Medicina Nuclear. Viabilizando o desenvolvimento das fontes radioativas de verificação (césio-137, bário-133 e cobalto-57) neste trabalho.

\subsection{Radioatividade e Aplicações das Fontes Radioativas Seladas}

Em 1896 o químico francês Henri Becquerel (1852-1908) descobriu que um minério de urânio emitia raios capazes de escurecer uma placa fotográfica, mesmo que a placa estivesse coberta por papel preto para evitar sua exposição à luz. Em 1898, Marie Curie e seus colaboradores isolaram o polônio e o rádio, que também emitiam o mesmo tipo de raios, e, em 1899, madame Curie sugeriu que os átomos de determinadas substâncias emitem esses raios incomuns quando se desintegram. Ela chamou esse fenômeno de radioatividade, e as substâncias que apresentam essa propriedade são ditas radioativas ${ }^{(15)}$.

Rutherford (1871-1937), afirmou que haveria ao menos dois tipos de radiação: Alfa $\alpha$, que era prontamente absorvida, e Beta $\beta$, de caráter mais penetrante. Subsequentemente, medidas da razão carga-massa mostraram que a radiação $\alpha$ é composta de núcleos de hélio $\left(\mathrm{He}^{2+}\right)$, e a $\beta$ é composta de elétrons (e-). Um terceiro tipo de radiação foi descoberto mais tarde por Paul Villard (1860-1934), denominada radiação Gama $(\gamma)$, que diferentemente das radiações $\alpha$ e $\beta$, não era desviada por campos elétricos ou magnéticos. Trata-se de uma forma de radiação eletromagnética como os raios-X, porém muito mais energética ${ }^{(15)}$.

A radiação beta se origina do núcleo do átomo. Pode se apresentar sob a forma de feixe de pósitrons $(\beta+)$ ou elétrons $(\beta-)$, apresentam alcance maior que as partículas alfa, 
podendo ser barradas por 1,0 $\mathrm{mm}$ de acrílico, uma folha de plástico ou alumínio e penetrar alguns centímetros na pele ${ }^{(16)}$.

Logo após a descoberta da radioatividade natural do urânio por Henri Becquerel, e a do rádio, pelo casal Curie, iniciaram-se os estudos e as atividades no sentido de empregá-los em diversas áreas ${ }^{(17)}$.

Uma variedade de fontes radioativas seladas de diferentes formas, tamanhos e níveis de radioatividade são utilizadas para aplicações importantes em muitos campos (18).

Uma fonte radioativa selada pode ser definida como um material radioativo totalmente encapsulado em um metal ou outro material de modo que não há nenhum contato entre o material radioativo e o meio exterior ${ }^{(18)}$.

$\mathrm{Na}$ indústria, elas são usadas para medições da taxa de fluxo, detecção de vazamentos, radiografia para inspecionar rachaduras em tubos de aço, medições de níveis de líquidos e espessura de sólidos, avaliação de recursos minerais, irradiação de alimentos entre outros usos ${ }^{(18)}$.

$\mathrm{Na}$ pesquisa, elas são usadas mais comumente para calibração de detectores de radiação e espectrômetros, análise elementar (análise de ativação neutrônica) e estudos da estrutura do material. Também o diagnóstico não-destrutivos do patrimônio cultural pode ser realizado utilizando fontes radioativas alfa, usando o que é chamado de PIXE (emissão de raios-X induzida por partículas) ${ }^{(18)}$.

$\mathrm{Na}$ medicina, elas são muito utilizadas em teleterapia e braquiterapia para o tratamento de doenças malignas, medições da densidade óssea, tratamento de câncer da próstata, do olho e podemos acrescentar calibração de equipamentos ${ }^{(18)}$.

A palavra braquiterapia tem origem grega $($ brachys $=$ curto; terapia $=$ tratamento) e define uma forma de tratamento que envolve a colocação de materiais radioativos junto ao tumor. Os materiais determinam a liberação de altas doses de radiação apenas nas proximidades da área de implantação, sem que um grande número de células normais saudáveis seja atingido ${ }^{(19,20,21)}$.

Embora a intervenção cirúrgica no tratamento de câncer ser a técnica mais utilizada, as taxas de recidiva são altas e este procedimento não é sempre possível de ser 
realizado. A radioterapia externa (teleterapia) também é bastante usada, porém também conta com suas desvantagens como os efeitos colaterais causados pela dose radioativa em tecidos $\operatorname{sadios}^{(22)}$.

Alguns exemplos bem conhecidos de fontes seladas, utilizadas para diversos fins, são as de ${ }^{60} \mathrm{Co},{ }^{57} \mathrm{Co},{ }^{63} \mathrm{Ni},{ }^{65} \mathrm{Zn},{ }^{90} \mathrm{Sr},{ }^{103} \mathrm{Pd},{ }^{106} \mathrm{Ru},{ }^{125} \mathrm{I},{ }^{137} \mathrm{Cs},{ }^{133} \mathrm{Ba},{ }^{166 \mathrm{~m}} \mathrm{Ho},{ }^{169} \mathrm{Yb},{ }^{192} \mathrm{Ir}$, ${ }^{241} \mathrm{Am} \mathrm{e}{ }^{210} \mathrm{P}{ }^{(18)}$.

Os níveis de radioatividade de tais fontes variam desde a ordem de $\mu \mathrm{Ci}$, usado para fins de calibração, até a ordem de vários milhares de curies, em irradiadores industriais e terapia com radiação ${ }^{(18)}$.

Existem muitos procedimentos para preparar núcleos de fontes seladas dependendo das propriedades físicas e químicas do material radioativo utilizado, do tipo e do nível de radioatividade e da finalidade do uso ${ }^{(18)}$.

\subsection{A Importância das fontes radioativas seladas para verificação de detectores na Medicina Nuclear}

A fim de estabelecer um padrão de segurança e precisão nas medidas das atividades de determinados radiofármacos utilizados na medicina, a Comissão Nacional de Energia Nuclear, a CNEN, criou a norma "Requisitos de Radioproteção e Segurança para Serviços de Medicina Nuclear" CNEN-NE-3.05, de abril de 1996, a qual estabelece que todo serviço de medicina nuclear deve possuir fontes padrão de referência de cobalto-57, bário-133 e césio 137, para aferição adequada dos seus detectores de radiação ou medidores de atividade ou calibradores de $\operatorname{dose}^{(3,23)}$.

De acordo com a norma CNEN-NN-3.05/2013, Resolução 159/13, o serviço de medicina nuclear, ou a quem ele delegar, deve realizar em seu medidor de atividade os testes descriminados na Tabela $1^{(24)}$. 
Tabela 1 - Testes obrigatórios para medidores de atividade (curiômetros) em medicina nuclear $^{(24)}$

\begin{tabular}{cccccc}
\hline Teste & Fonte & Frequência & $\begin{array}{c}\text { Desvios } \\
\text { permitidos }\end{array}$ & Confiabilidade & Variação \\
\hline Exatidão & $\begin{array}{c}{ }^{57} \mathrm{Co}, \\
{ }^{133} \mathrm{Ba},\end{array}$ & Semestral & $10 \%$ & $90 \%$ & - \\
& ${ }^{137} \mathrm{Cs}$ & & & & \\
Precisão & ${ }^{57} \mathrm{Co}$, & & & & \\
& ${ }^{133} \mathrm{Ba}$, & Semestral & $5 \%$ & $95 \%$ & \\
Reprodutibilidade & ${ }^{137} \mathrm{Cs}$ & & & & \\
Linearidade & ${ }^{137} \mathrm{Ba}$, & Anual & $5 \%$ & $95 \%$ & $\pm 20 \%$ \\
\hline
\end{tabular}

Os medidores de atividade são equipamentos amplamente empregados pelos serviços de medicina nuclear, para a avaliação da atividade dos radioisótopos utilizados para propósitos diagnósticos e terapêuticos. A medida da atividade dos radioisótopos deve ser feita com exatidão, pois será administrada em um paciente ${ }^{(25)}$. Na Figura 1 é mostrado diferentes medidores de câmara de ionização do fabricante Capintec, modelos CRC-15W (com detector de iodeto de sódio com tálio - NaI(Tl) e câmara de ionização) CRC-15R (contando somente com detector de câmara de ionização) e CRC-15BT (mais utilizado para radiação $\beta$ ).

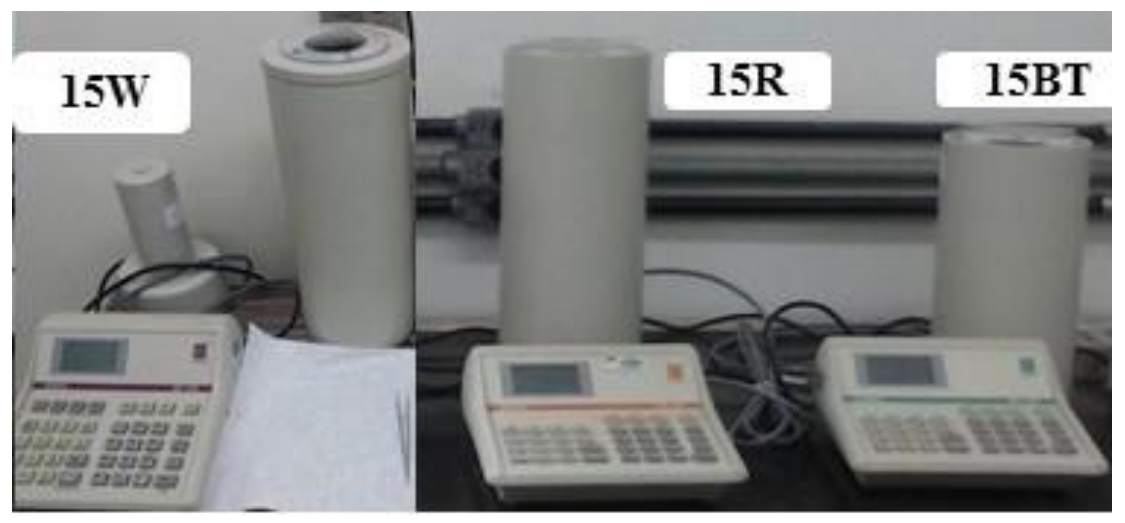

Figura 1 - Detectores modelos CRC-15W, CRC-15R e CRC BT. 
O estudo para a confecção dessas fontes radioativas seladas de verificação, visa atender essas necessidades disponibilizando sua produção nacional, objetivando a redução dos custos relacionados a importação.

\subsection{Fontes Radioativas Seladas Imobilizadas em Resina Epóxi}

Matrizes de epóxi solidificadas em estado vítreo tem alta resistência a compressão $\left(500-700 \mathrm{~kg} / \mathrm{cm}^{2}\right)$ e força de adesão de $100 \mathrm{~kg} / \mathrm{cm}^{2}$. Investigações sobre a resistência à radiação, por exemplo, de compostos radioativos, mostraram que a matriz permanece inalterada com doses de radiação gama de até $100 \mathrm{MGy}$, porém houve aumento da elasticidade e diminuição da fratura por tração com a dose de radiação. Nenhum vazamento de fontes produzidas com césio-137 foi observado durante um período de dois anos de testes ${ }^{(26)}$.

As fontes radioativas seladas são fontes de materiais radioativos imobilizadas em resina equivalente a água com distribuição homogênea em solução aquosa com densidade ao redor de $1 \mathrm{~g} / \mathrm{cm}^{3}$; similar à da água. Estas fontes geralmente são emissores gama com energia ao redor de $100 \mathrm{keV}$ a $700 \mathrm{keV}$ com tempo de meia vida longo $(26,27,28)$

Os radionuclídeos recomendados para aplicação como fontes seladas para verificação dos medidores de atividade são ${ }^{57} \mathrm{Co},{ }^{133} \mathrm{Ba} \mathrm{e}{ }^{137} \mathrm{Cs}$. Na Tabela 2 é mostrada algumas especificações desses radionuclídeos ${ }^{(24,29)}$.

Tabela 2 - Atividades e meias vidas das fontes radioativas solidas importadas, que são produzidas no laboratório alemão de fontes radioativas seladas da Eckert \& Ziegler Isotope Products $(\mathrm{E} \& Z)^{(29,30)}$.

\begin{tabular}{|c|c|c|c|c|c|}
\hline Radionuclídeos & $\begin{array}{c}\text { Tipo } \\
\text { de } \\
\text { Desintegração }\end{array}$ & $\begin{array}{c}\text { Energia } \\
\text { Fóton } \\
\text { Principal } \gamma \\
(\mathbf{k e V})^{(30)}\end{array}$ & $\begin{array}{c}\text { Energia } \\
\text { Máxima } \\
\text { dos } \boldsymbol{\beta}^{-} \\
(\mathbf{k e V})^{(\mathbf{3 0})}\end{array}$ & $\begin{array}{c}\text { Tempo } \\
\text { de Meia } \\
\text { vida }^{(30)}\end{array}$ & $\begin{array}{c}\text { Atividade } \\
\mathbf{M B q}^{(29)}\end{array}$ \\
\hline${ }^{57} \mathrm{Co}$ & $\begin{array}{c}\text { C.E. (captura } \\
\text { eletrônica) } \\
\text { com } \gamma\end{array}$ & 122,061 & - & $\begin{array}{c}271,80 \\
\text { dias }\end{array}$ & 185 \\
\hline${ }^{133} \mathrm{Ba}$ & C.E. com $\gamma$ & $80,998 \mathrm{e}$ & - & $\begin{array}{c}10,54 \\
\text { anos }\end{array}$ & 9,3 \\
\hline${ }^{137} \mathrm{Cs}$ & $\gamma, \beta^{-}$ & 661,657 & 1175,63 & $\begin{array}{c}30,05 \\
\text { anos }\end{array}$ & 7,4 \\
\hline
\end{tabular}


Estas fontes já são desenvolvidas no Instituto de Pesquisas Energéticas e Nucleares (IPEN). Na Figura 2 é mostrada as três fontes de calibração produzidas no Centro de Tecnologia das Radiações IPEN.

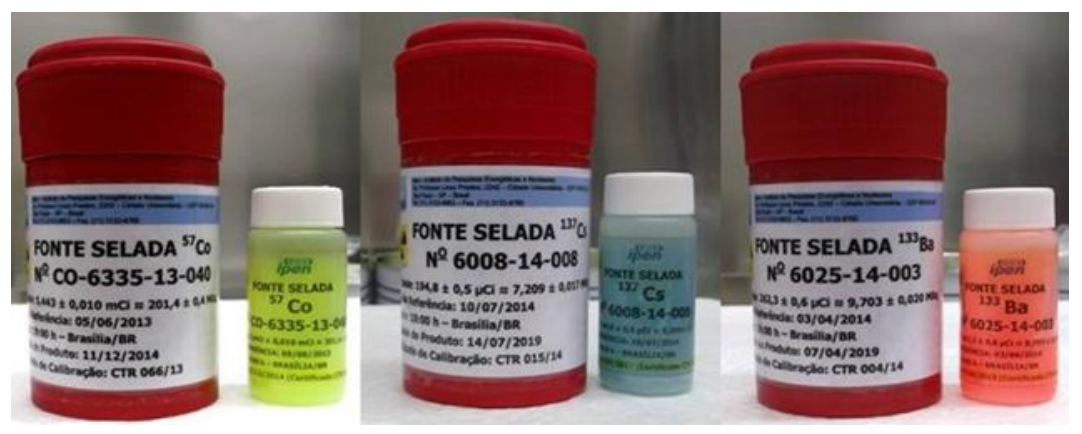

Figura 2 - Fontes radioativas seladas com resina epóxi produzidas no CTR-IPEN

Os procedimentos para produção e validação destas fontes devem atender aos critérios estabelecidos nas normas ISO 2919 e ISO $9978^{(31,32)}$.

\section{OBJETIVOS}

\subsection{Gerais}

Este trabalho tem como objetivo o estudo e desenvolvimento da imobilização de bário-133 e césio-137, em matriz polimérica de modo a criar fontes radioativas seladas para verificação de detectores utilizados no serviço de medicina nuclear. Nacionalizando a produção destas fontes.

\subsection{Específicos}

- Estudo dos detectores de câmaras de ionização disponíveis no Centro de Tecnologia das Radiações - IPEN utilizando fontes importadas, realizando os testes de precisão e exatidão.

- Escolha da resina epóxi rígida comercial mais adequada para o desenvolvimento da fonte. 
- Estudo das características da resina epóxi rígida escolhida para imobilização do material radioativo, analisando a máxima capacidade de miscibilidade da resina com a água (solução ácida, simulando as condições da solução radiativa), propriedades mecânicas (resistência à tração e à compressão) e propriedades térmicas (análise termogravimétrica).

- Estudo da aceleração do processo de cura por radiação gama, testes mecânicos e térmicos da resina curada.

- $\quad$ Produção das fontes radioativas de verificação (bário-133 e césio-137) seladas com a resina.

- Análise da homogeneidade da distribuição do material radioativo no conjunto final.

- Execução dos testes de estanqueidade normalizados pela ISO 9978, norma

"International Standard Organization Radiation protection - leakage test methods", a fim de validar a qualidade da selagem do bário-133 e césio137 na matriz polimérica.

\section{REVISÃO DA LITERATURA}

\subsection{Resina Epóxi Rígida}

A palavra epóxi vem do grego "EP"(sobre ou entre) e do inglês "OXI"(oxigênio), literalmente o termo significa oxigênio entre carbonos. Em um sentido geral, o termo refere-se a um grupo constituído por um átomo de oxigênio ligado a dois átomos de carbono $^{(33)}$.

O Grupo epóxi mais simples é aquele formado por um anel de 03 elementos. O método mais utilizado para sua síntese é a reação de um alceno com o ácido peróxido orgânico, processo chamado de epoxidação. O processo pode ser iniciado simplesmente pela adição de um catalisador nucleofílico, como um alcóxido ou amina ${ }^{(33)}$. 
A maior parte das resinas epóxi é obtida a partir da condensação de epicloridrina (1-cloro-2,3-epóxi propano) e bisfenol A [2,2-bis (4-hidroxifenil) propano], conhecidas como copolímeros do diglicidil éter do bisfenol-A ou simplesmente DGEBA ${ }^{(26)}$.

A molécula mostrada na Figura 3 é a resina epóxi antes de ser catalisada podendo, dependo do valor de $\mathrm{n}$, ser líquida a até sólida sendo que a viscosidade aumenta conforme vai aumentando o $\mathrm{n}$. Com $\mathrm{n}<\mathrm{ou}=1$ teremos resinas líquidas $\mathrm{e} n>1$ começará as resinas semi-sólidas e sólidas. Podem ser classificadas através do EEW (equivalent epoxy weight) ou seu peso equivalente em epóxi. A grosso modo as líquidas ficam até 229, as semi-sólidas de 230 a 459 e as sólidas acima de 460 podendo chegar a até 5000. O EEW é utilizado para cálculo estequiométrico de proporção entre resina e endurecedor. A resina básica líquida é a de $\mathrm{EEW}=190$. O cálculo do EEW é simplesmente o peso molecular da resina dividido pelo $n^{\circ}$ de anéis epoxídicos ${ }^{(33)}$.

$$
\text { EEW = peso molecular da resina / no de anéis epoxídicos }{ }^{(33)}
$$

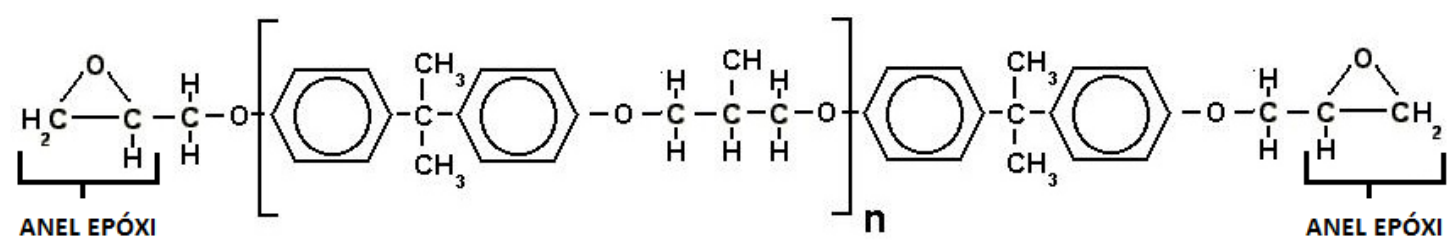

Figura 3 - Molécula de resina epoxídica (diglicidil éter do bisfenol A - DGEBA) ${ }^{(33)}$

\subsubsection{Agente de cura}

Nos principais campos da moderna tecnologia industrial, a aplicação das resinas epóxi vem sofrendo um grande aumento. Sua versatilidade é devida a grande reatividade do anel epóxi, pois um considerável número de compostos químicos, tais como aminas alifáticas e aromáticas, anidridos e poliamidas, podem ser empregados na abertura do anel, e consequentemente reticulação da resina. Desse modo, diversos sistemas epóxi podem ser produzidos, obtendo-se diferentes propriedades mecânicas, físicas e químicas em função do tipo do composto, ou seja, do endurecedor empregado para abrir o anel ${ }^{(34)}$. 
As resinas epóxi podem ser curadas com vários agentes de cura (também chamados de endurecedores), por aminas, anidridos, isocianatos e até mesmo por radiação eletromagnética ${ }^{(35)}$.

$\mathrm{O}$ endurecedor à base de poliamina modificado da dietilenotriamina (DETA) promove a melhor adesão com boa resistência térmica, química e mecânica com baixa exotermia, possuindo boa solubilização na resina com proporções não críticas, permitindo cura homogênea com boa velocidade e propriedades finais bastante controláveis ${ }^{(35)}$.

As características apresentadas por esses materiais são resultados do processo de polimerização ou cura, no qual a resina de baixa massa molecular é transformada em um polímero de alta massa molecular, devido à formação de ligações cruzadas ${ }^{(35)}$.

Durante um processo típico de cura de uma resina DGEBA, os grupos amínicos do agente de cura interagem com os anéis epoxídicos tensionados, causando o rompimento da ligação covalente entre os átomos de oxigênio e carbono, que por sua vez se ligam covalentemente com o átomo de nitrogênio presente no agente de cura. Essa reação gera elevada densidade de ligações cruzadas solidificando o polímero como é mostrada na Figura $4^{(35)}$.

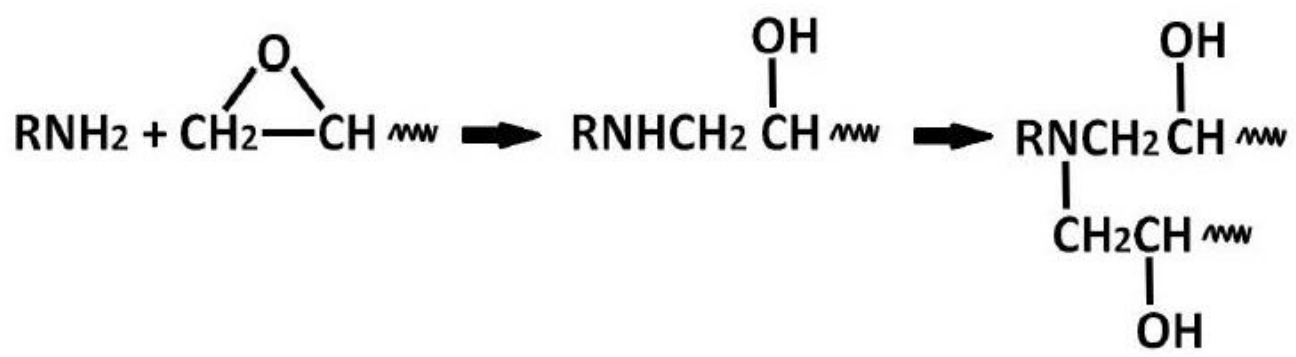

Figura 4 - Esquema do processo de reação da cura do epóxi ${ }^{(35)}$.

\subsubsection{Características da Resina Epóxi Curada e Miscibilidade com a água.}

A resina epóxi é um dos polímeros termofixos mais utilizados por apresentar baixa retração durante a cura, excelente adesão a uma variedade de superfícies, boa estabilidade dimensional, baixa absorção de umidade, boas propriedades térmicas e elétricas, excelente resistência química e a intempéries com alta relação resistência/peso $(34,36,37)$ 
As resinas de imobilização do material radioativo, devem permanecer estáveis em soluções de água, incluindo soluções ácidas e alcalinas, não devendo ultrapassar mais do que $25 \%{ }^{(26,33)}$.

\subsubsection{Irradiação de polímeros - Melhoria das propriedades mecânicas}

O uso da irradiação em polímeros vem crescendo cada vez mais devido à grandes possibilidades de modificação de suas propriedades, minimizando ou evitando o uso de solventes, iniciadores ou aditivos potencialmente tóxicos. Os polímeros têm uma grande variação em sua interação com a radiação ionizante ${ }^{(38)}$.

A interação da radiação ionizante com polímeros resulta na formação de moléculas ionizadas e moléculas excitadas que posteriormente se recombinam ou dissociam para produzir radicais livres ou íons. $\mathrm{O}$ excesso de íons é neutralizado pelo processo de solvatação. A formação de radicais livres é o processo mais importante da interação da radiação ionizante com os polímeros. Estes radicais livres têm uma participação importante nas reações químicas que ocorrem nos polímeros irradiados ${ }^{(38)}$.

Além destes radicais e íons formados outros efeitos da radiação ionizante em materiais poliméricos são a reticulação e a degradação ${ }^{(38)}$.

A reticulação é a formação de ligações químicas entre as cadeias moleculares formando estruturas tridimensionais interligadas, e a degradação é a destruição da estrutura molecular do polímero, formando moléculas menores, oligômeros e monômeros ${ }^{(38)}$.

As transformações estruturais, induzidas pela radiação ionizante, produzem mudanças nas propriedades físicas e mecânicas dos materiais irradiados. Ainda que a radiação e a degradação ocorram simultaneamente durante a irradiação do polímero, um destes processos é geralmente predominante, dependendo da estrutura química do polímero, da dose, da taxa de dose e tipo de radiação e das condições (meio pressão e temperatura) nas quais o material é irradiado ${ }^{(38)}$. 
Os tipos de radiações ionizantes mais empregados em processos industriais são a radiação gama, proveniente de fontes radioisotópicas e feixe de elétrons de alta energia proveniente de aceleradores ${ }^{(38)}$.

A resina epóxi rígida quando submetida a uma certa dose de irradiação, pode sofrer reticularão induzida pela irradiação, ocorrendo melhoria de suas propriedades físicas e químicas ${ }^{(39)}$.

\subsection{Fontes Radioativas Seladas Imobilizadas em Resina Epóxi}

A resina comercial epóxi rígida DGEBA, merecem grande interesse para serem empregadas na confecção de matrizes poliméricas de imobilização de material radioativo: ${ }^{(26,40)}$

- São das mais antigas resinas da classe epóxi oferecendo custos menores, facilidade de aquisição e disponibilidade no mercado.

- Têm baixa toxicidade e, consequentemente, possibilidade baixa de contaminação química durante sua manipulação.

- $\quad$ O processo de cura leva à obtenção de material polimérico de elevada resistência à compressão e força de adesão e com alta resistência à radiação, bem como elevada resistência à decomposição térmica, que os tornam um material com alta estabilidade química.

- O processo de cura origina também polímeros praticamente insolúveis em água, seja em meio ácido ou alcalino, que dificulta o vazamento ou difusão do componente radioativo mesmo quando imersos nestes citados meios.

- As resinas epóxi comerciais, em sua grande maioria, não contém quantidades significativas de impurezas radioativas, levando a exibir um background muito baixo, não comprometendo, portanto a atividade total e os procedimentos de calibração da fonte selada. 
Uma fonte radioativa selada pode ser definida como: material radioativo permanentemente selado em uma ou várias cápsulas e/ou associado a um material ao qual se encontra imobilizado (no caso do estudo resina). Essas cápsulas ou materiais devem ser resistentes o suficiente para manter a ausência de vazamento na fonte selada, sob condições de uso e desgaste para as quais foi projetada ${ }^{(41)}$.

O processo de manufatura de uma fonte selada padrão em matriz epóxi consiste no envasamento, em um frasco de geometria padronizada, de uma quantidade, em volume fixo, de uma matriz polimérica no interior da qual é adicionada e dispersada homogeneamente uma quantidade precisa e exata em atividade de um material radioativo padrão ${ }^{(42)}$.

A matriz polimérica apresenta a função primordial de fixar e imobilizar o conteúdo radioativo não permitindo seu vazamento dentro dos limites técnicos exigidos pelas normas de proteção radiológica no quesito de características de uma fonte selada e, adicionalmente, ter a capacidade de reter a emanação de quaisquer gases que venham a se formar durante o processo de fabricação e do período de vida útil deste artefato ${ }^{(42)}$.

\subsubsection{Fontes Radioativas Seladas de Verificação de Detectores usadas no Serviço de Medicina Nuclear.}

As fontes radioativas em resina equivalente à água são utilizadas em diversas aplicações tais como: medicina nuclear (verificação de detectores), radioterapia e análise ambiental. Estas fontes devem apresentar parâmetros físicos (volume, densidade, número atômico efetivo e coeficiente de atenuação gama) semelhantes aos das fontes radioativas líquidas. Isto é necessário para que o espectro das radiações emitidas pela fonte em resina seja equivalente ao das líquidas. E por serem sólidas não estão sujeitas a quebra e a contaminações. Estas fontes são preparadas a partir de soluções radioativas de Co-57, Cs-137 e Ba-133, elas possuem densidade similar à da água e boa uniformidade $^{(42)}$.

Na Figura 5 é mostrado um esquema de uma fonte fabricada pela empresa Alemã Eckert \& Ziegler Isotope Products (E\&Z). 
Cada fonte padrão é fornecida em frasco de polietileno de $27 \mathrm{ml}$ com distribuição uniforme do elemento ativo em $20 \mathrm{ml}$ de resina epóxi, composto por uma densidade de aproximadamente $1,0 \mathrm{~g} / \mathrm{cm}^{3}{ }^{(43)}$.

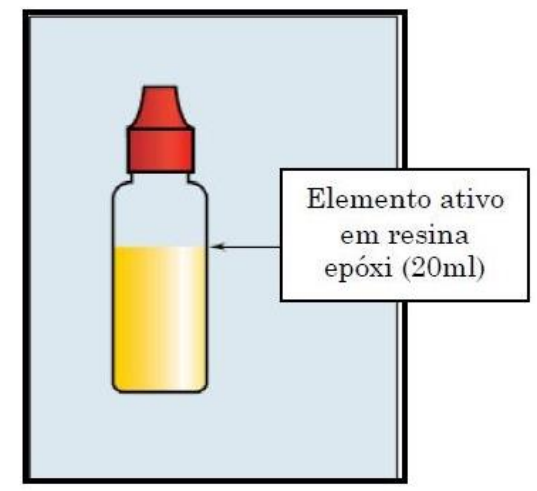

Figura 5 - Esquema de uma fonte padrão Eckert \& Ziegler ${ }^{(43)}$

\subsubsection{Descrição de um Detector de Câmara de Ionização tipo poço usado no Serviço de Medicina Nuclear}

A aceitação geral dos calibradores de dose pelos serviços de medicina nuclear deve-se a sua simplicidade de operação, estabilidade a curto e a longo prazos e sua versatilidade de operação, permitindo a medição da atividade de soluções radioativas em frascos, seringas e ampolas ${ }^{(44)}$.

No caso das fontes de verificação, a geometria da fonte deve ser próxima da geometria dos frascos utilizados que contém os radiofármacos, para a medição, pois uma das maiores fontes de erros nas medidas realizadas com um ativímetro deve-se a geometria do frasco que está sendo utilizado no momento do procedimento ${ }^{(43)}$.

A norma da Comissão Nacional de Energia Nuclear (CNEN NN 3.05) que estabelece os requisitos de radioproteção e segurança para os serviços de medicina nuclear adota o termo curiômetro para definir o instrumento destinado a medir a atividade de radionuclídeos utilizados em medicina nuclear, em vez do termo mais comum, criado comercialmente, calibrador de dose. No último termo, dose quer dizer dose farmacêutica, isto é, a quantidade prescrita de uma substância a ser administrada para propósitos médicos. Este termo pode ser mal interpretado como dose absorvida ou como dose equivalente, que são grandezas radiológicas coincidentemente também 
aplicáveis ao uso de radionuclídeos em medicina nuclear. Por este motivo, a popularização do termo calibrador de dose é infeliz. Na Argentina foi adotado o termo espanhol para calibradores de atividade ("calibradores de actividad"). Cientistas franceses introduziram o termo "actvimètre", que em espanhol pode ser adaptado como "activímetro". Este termo utiliza a palavra grega "metron" (medição ou instrumento de medição) em vez de calibrador, também sujeito a críticas. No Brasil, o termo curiômetro utiliza a palavra curie (nome da unidade de atividade anteriormente empregada). Como o curie (Ci) não faz parte do Sistema Internacional, devendo ser substituída pelo becquerel $(\mathrm{Bq})$, talvez o mais correto seria usar o termo medidor de atividade ${ }^{(44)}$.

Neste trabalho resolveu-se adotar o termo pelo tipo de detector usado, detector de câmara de ionização.

O detector tem uma característica única em relação a outros sistemas que utilizam câmaras de ionização, que é o seu circuito eletrônico permitindo que a resposta do instrumento seja mostrada diretamente em unidades de atividade ${ }^{(1)}$.

Além de sua câmara de ionização, o detector é constituído de outros componentes relacionados a seguir e apresentado na Figura 6: ${ }^{(43)}$

- uma fonte de tensão estabilizada para proporcionar a polarização adequada a câmara.

- um eletrômetro adequado para a medida das correntes de ionização baixas.

- um circuito eletrônico para processamento e apresentação dos dados.

- dispositivos de visualização e impressão de resultados das medidas.

- dispositivos para a colocação de fontes radioativas em recipientes de diversos tamanhos e formas.

- interface para seleção de opções e introduções de dados. 


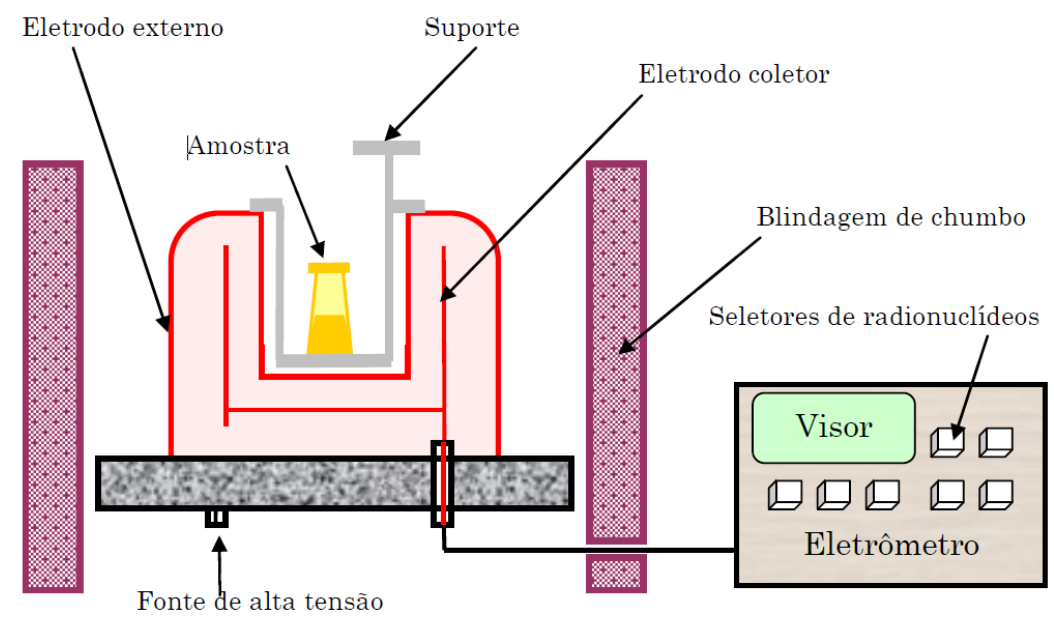

Figura 6 - Esquema de um detector câmara de ionização ${ }^{(43)}$

Além dos componentes citados anteriormente o detector possui uma câmara de ionização com formato de poço na sua região central para a inserção do suporte de acrílico que contém a amostra radioativa a ser medida ${ }^{(43)}$.

Dependendo da quantidade radioativa da amostra inserida na câmara é produzida uma quantidade de corrente, assim radionuclídeos diferentes com a mesma quantidade de atividade não produzem a mesma corrente, apresentando certa dependência energética ${ }^{(43)}$.

A câmara de ionização do detector é selada e o gás da câmara é mantido sob pressão bastante superior a atmosfera, normalmente entre 10 e 20 atmosferas ${ }^{(43)}$.

Os detectores preferencialmente são utilizados para medições de radionuclídeos emissores de radiação gama. Ao aplicar uma diferença de potencial entre os eletrodos da câmara, fornecida pela fonte de tensão, os fótons ao interagirem com o gás no interior da câmara produzem ionização originando duas cargas elétricas (pares iônicos) ${ }^{(3)}$.

As cargas são atraídas eletricamente para o eletrodo, mas com polaridade contrária à sua como é mostrada na Figura 7, gerando uma pequena corrente elétrica. Através do eletrômetro a corrente de ionização é convertida em sinal, amplificado, processado e apresentado em seu visor digital por meio de medidas diretas da atividade dos radionuclídeos na ordem de múltiplos ou submúltiplos de unidades de medidas em becquerel ou curie, respectivamente. Isso ocorre devido às condições geométricas serem as mesmas, pois a resposta é linear e diretamente proporcional à atividade. No entanto, a resposta de uma câmara de ionização pode variar de acordo com o tipo de radiação, e principalmente a energia do radionuclídeo necessitando de ajustes na amplificação do 
sinal. Por esse motivo a maioria dos ativímetros possui teclas de seleção para diversos tipos de isótopos ${ }^{(43)}$.

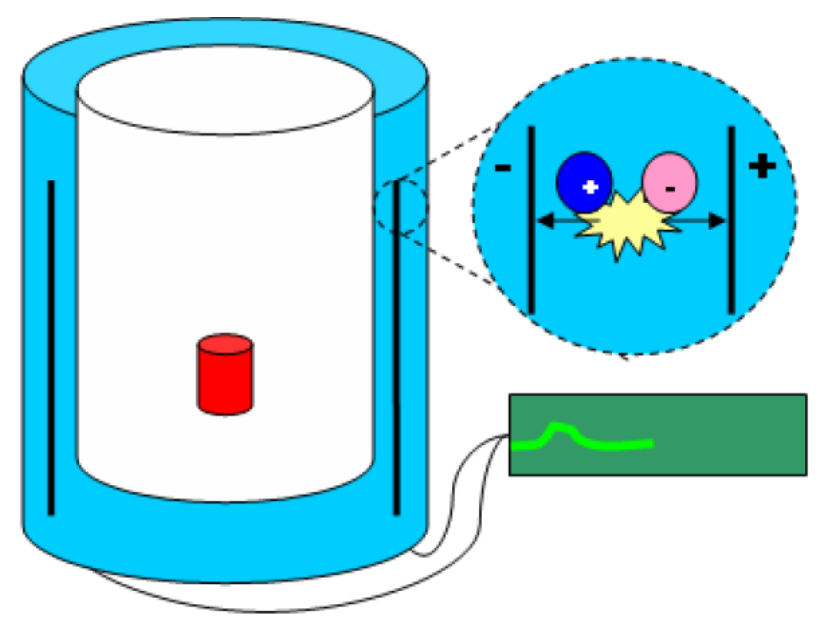

Figura 7 - Esquema da câmara de ionização do detector ${ }^{(43)}$

A blindagem ao redor do poço (câmara de ionização) é uma medida de proteção radiológica e também contribui para a redução da radiação de fundo. A espessura da parede de uma câmara deve ser relativamente grande para suportar a pressão do gás emanado. Devido à colocação da fonte no interior do poço a dependência da resposta da câmara, da posição e forma de uma fonte é minimizada ${ }^{(43)}$.

\subsection{Classificação e estanqueidade de fontes radioativas seladas- Normas ISO 9978 e ISO 2919}

Para garantir conformidade com as exigências de proteção radiológica, critérios no desenvolvimento e fabricação das fontes seladas foram estabelecidos pelas normas "Radiation protection - sealed radioactive sources - General requirements and classification" ISO $2919^{(31)}$ e "Radiation protection - sealed radioactive sources leakage test methods" ISO $9978^{(32)}$.

De acordo com as normas, as fontes seladas devem ser avaliadas em vários critérios, devem ser classificadas analisando a toxicidade do radioisótopo. Posteriormente, devem ser feitos testes para determinar o desempenho do produto expondo-o a temperatura, pressão externa, vibração e funcionamento específicos para cada fonte ${ }^{(31,32)}$. 
A aprovação em qualquer um dos ensaios será determinada pela capacidade da fonte selada em manter sua estanqueidade ao final do mesmo. Após cada ensaio, a fonte deverá ser examinada visualmente para constatar sua integridade e também deverá ser aprovada em teste de vazamento, realizado de acordo com a norma "International Standard Organization Radiation protection - leakage test methods" ISO $9978^{(32)}$.

No anexo A da norma ISO 9978, é apresentada uma tabela com recomendações para que o usuário possa tomar como guia na escolha do método mais conveniente ao tipo de fonte que irá produzir. As fontes radioativas sólidas de cobalto-57, bário-133 e césio137 pertencem a classificação "A" da Tabela 3:(32)

Tabela 3 - Seleção dos métodos de testes de vazamento ${ }^{(32)}$

\begin{tabular}{|c|c|c|c|c|}
\hline \multirow{2}{*}{ Tipo de Fonte } & \multicolumn{2}{|c|}{$\begin{array}{l}\text { Testes para produção de } \\
\text { fontes }\end{array}$} & \multicolumn{2}{|c|}{$\begin{array}{c}\text { Testes para caracterização } \\
\text { de fontes }\end{array}$} \\
\hline & Preferido & $\begin{array}{l}\text { Segundo } \\
\text { Método }\end{array}$ & Preferido & $\begin{array}{c}\text { Segundo } \\
\text { Método }\end{array}$ \\
\hline $\begin{array}{c}\text { A - Fontes seladas } \\
\text { contendo material } \\
\text { radioativo } \\
\text { A1 - Janela única e fina, } \\
\text { por exemplo, detectores } \\
\text { de fumaça } \\
\text { A2 - Fontes de referência } \\
\text { de baixa atividade, por } \\
\text { exemplo, encapsuladas } \\
\text { em plástico }\end{array}$ & $\begin{array}{l}\text { Imersão } \\
(\mathbf{5 . 1})\end{array}$ & $\begin{array}{c}\text { Vazamento } \\
(\mathbf{5 . 3 )}\end{array}$ & $\underset{(5.1)}{\text { Imersão }}$ & $\begin{array}{c}\text { Vazamento } \\
(\mathbf{5 . 3 )}\end{array}$ \\
\hline \multirow{2}{*}{$\begin{array}{l}\text { A3 - Fontes encapsuladas } \\
\text { uma ou duas vezes } \\
\text { (excluindo Trítio e Rádio) } \\
\text { para medição, radiografia } \\
\text { e Braquiterapia }\end{array}$} & $\begin{array}{l}\text { Imersão } \\
(5.1)\end{array}$ & \multirow[t]{2}{*}{ Bolhas (6.2) } & Imersão (5.1) & \multirow[t]{2}{*}{ Bolhas (6.2) } \\
\hline & Hélio (6.1) & & Hélio (6.1) & \\
\hline $\begin{array}{c}\text { A4 - Fontes encapsuladas } \\
\text { uma ou duas vezes de } \\
\text { Rádio e outras fontes } \\
\text { gasosas } \\
\end{array}$ & $\begin{array}{l}\text { Emanação } \\
\text { gasosa } \\
(5.2)\end{array}$ & Imersão (5.1) & $\begin{array}{l}\text { Emanação } \\
\text { gasosa (5.2) }\end{array}$ & Imersão (5.1) \\
\hline A5 - Fontes encapsuladas & & & Imersão (5.1) & \\
\hline $\begin{array}{l}\text { duas vezes para } \\
\text { teleterapia e fontes de alta } \\
\text { atividade de irradiação }\end{array}$ & Hélio (6.1) & & Hélio (6.1) & Bolhas (6.2) \\
\hline \multirow{2}{*}{$\begin{array}{c}\text { B - Fontes simuladas } \\
\text { seladas dos tipos A3, A4 } \\
\text { e A5 }\end{array}$} & & & Imersão (5.1) & \multirow[b]{2}{*}{ Bolhas (6.2) } \\
\hline & & & Hélio (6.1) & \\
\hline $\begin{array}{c}\mathrm{C}-\text { Fontes seladas do } \\
\text { tipo "Dummy" }\end{array}$ & & & $\begin{array}{c}\text { Imersão (5.1) } \\
\text { Hélio }(6.1)\end{array}$ & Bolhas (6.2) \\
\hline
\end{tabular}


A norma determina quatro tipos de testes de imersão: ${ }^{(32,45)}$

I. Teste de imersão em líquido quente.

Imersão da fonte selada em um líquido que não ataque o material externo da fonte e que seja considerado efetivo para a remoção de qualquer material radioativo presente. $\mathrm{O}$ líquido é aquecido e a fonte fica em banho por tempo e temperatura determinados. A fonte é removida e é medida a atividade do líquido.

II. Teste de imersão em líquido fervente.

A fonte é colocada em líquido fervente, que não ataque o material externo da fonte e que seja considerado efetivo para a remoção de qualquer material radioativo externo. A fonte é fervida três vezes por 10 minutos cada, sempre no mesmo líquido. A fonte não deve ser enxaguada com líquido frio. Retira-se a fonte e mede-se a atividade do líquido.

III. Teste de imersão em líquido cintilador.

Colocar a fonte em uma solução cintiladora que não ataque o material externo da fonte em temperatura ambiente por 3 horas ao abrigo da luz. A atividade da solução cintiladora é medida utilizando técnica de contagem com líquido cintilador.

IV. Teste de imersão a temperatura ambiente.

Imersão da fonte em líquido que não ataque o material externo da fonte e que seja considerado efetivo na remoção de qualquer material radioativo externo. A fonte é deixada nessa situação a temperatura ambiente por 24 horas. A fonte é removida e mede-se atividade do líquido.

Após qualquer um dos testes de imersão realizados, a fonte é considerada estanque se a atividade detectada não exceder $185 \mathrm{~Bq}(\approx 5 \mathrm{nCi}){ }^{(32,45)}$.

O teste de vazamento pode ser realizado esfregando-se um tecido, que pode estar umedecido em água ou etanol. Esse tecido tem posteriormente sua atividade analisada. $\mathrm{A}$ atividade não pode exceder $185 \mathrm{~Bq}(\approx 5 \mathrm{nCi})^{(32,45)}$.

\section{MATERIAIS E MÉTODOS}

Neste capítulo são apresentadas as metodologias utilizadas na busca de se alcançar os objetivos apresentados para este trabalho. 


\subsection{Escolha da resina epóxi rígida comercial mais adequada para o desenvolvimento da fonte}

Nosso grupo do Centro de Tecnologia das Radiações - IPEN já utiliza a resina epóxi rígida para produção dessas fontes de calibração, sendo assim, foram analisadas duas formulações comercias de resina epóxi rígida.

Essas matrizes devem possuir densidade em torno de $1 \mathrm{~g} / \mathrm{cm}^{3}$, similar à da água. Tal similaridade é necessária para que haja reprodutibilidade na aferição das soluções de radiofármacos, dissolvidas em água. Essas fontes são utilizadas na aferição de medidores de atividade (curiômetros). As matrizes epóxi também já são utilizadas para selagem de rejeitos radioativos, possuem uma alta densidade de grupos aromáticos o que lhes dá grande resistência a radiação ${ }^{(27)}$.

As duas formulações resinas epóxi rígidas analisadas foram as seguintes:

\section{- A resina SQ2001 (diglicil éter de bisfenol-A modificado) da Silaex.}

Esta resina possui, segundo sua ficha técnica, densidade de $1,16 \pm 0,02 \mathrm{~g} / \mathrm{cm}^{3}$ a $20^{\circ} \mathrm{C}$, e utiliza-se o endurecedor SQ3454 ${ }^{(46)}$.

Esta resina não foi escolhida, pois na mistura da resina com o endurecedor, devido a uma maior reatividade, ocorreu respingo para fora do recipiente da mistura, sendo assim, não é viável para produção das fontes radioativas.

\section{- A resina SQ2004 (diglicil éter de bisfenol-A modificado) da Silaex.}

Esta resina possui, segundo sua ficha técnica, densidade de $1,12 \pm 0,02 \mathrm{~g} / \mathrm{cm}^{3}$ a $20^{\circ} \mathrm{C}$, e utiliza-se o endurecedor SQ3131 (3-aminometil-3,5,5-trimetilcicloesilamina) ${ }^{(47)}$.

Esta foi a resina escolhida para os testes e desenvolvimento das fontes.

\subsection{Estudo das propriedades da resina epóxi rígida escolhida.}

Foram definidas 5 formulações para os testes realizados neste trabalho, como mostrado na Tabela 4. Para simular diferentes concentrações da solução do radioisótopo na resina, preparou-se uma mistura de resina epóxi e endurecedor poliamínico, respectivamente, na proporção de 100:20 partes em peso, sobre os quais foram 
adicionadas quantidades variáveis de solução aquosa $0,1 \mathrm{M}$ em $\mathrm{HCl}$ preparada em água destilada e de modo a perfazer 5, 10, 15, 20 e $25 \%$ em massa de água na mistura resinaendurecedor.

Tabela 4 - Formulações de resina epóxi rígida

\begin{tabular}{|c|c|c|c|}
\hline Fórmula & Resina SQ 2004 & $\begin{array}{c}\text { Endurecedor } \\
\text { SQ } 3131\end{array}$ & $\begin{array}{l}\text { Porcentagem da Solução HCI } 0,1 \mathrm{M} \\
\text { sobre o peso total da Resina }(60 \mathrm{~g})\end{array}$ \\
\hline Epoxi 0 & \multirow{6}{*}{$50 \mathrm{~g}$} & \multirow{6}{*}{$10 \mathrm{~g}$} & $0 \%$ \\
\hline Epoxi 5 & & & $5 \%$ \\
\hline Epoxi 10 & & & $10 \%$ \\
\hline Epoxi 15 & & & $15 \%$ \\
\hline Epoxi 20 & & & $20 \%$ \\
\hline Epoxi 25 & & & $25 \%$ \\
\hline
\end{tabular}

Foram preparadas também formas de silicone como molde para as peças feitas com a resina epóxi para os testes de tração seguindo a norma ASTM D638-03 ${ }^{(48,50)}$ e compressão segundo a norma ASTM D695-08 ${ }^{(50)}$. Essas formas, mostradas na Figura 8, foram confeccionadas com borracha de silicone da mesma fabricante da resina. Borracha de silicone SQ8320 (mistura de polímero de siloxana hidróxi-funcional) e catalisador de silicone 70 (catalisador para borracha de silicone RTV-2). São usados 3\% de catalisador sobre o peso total da borracha de silicone para sua preparação ${ }^{(51)}$.
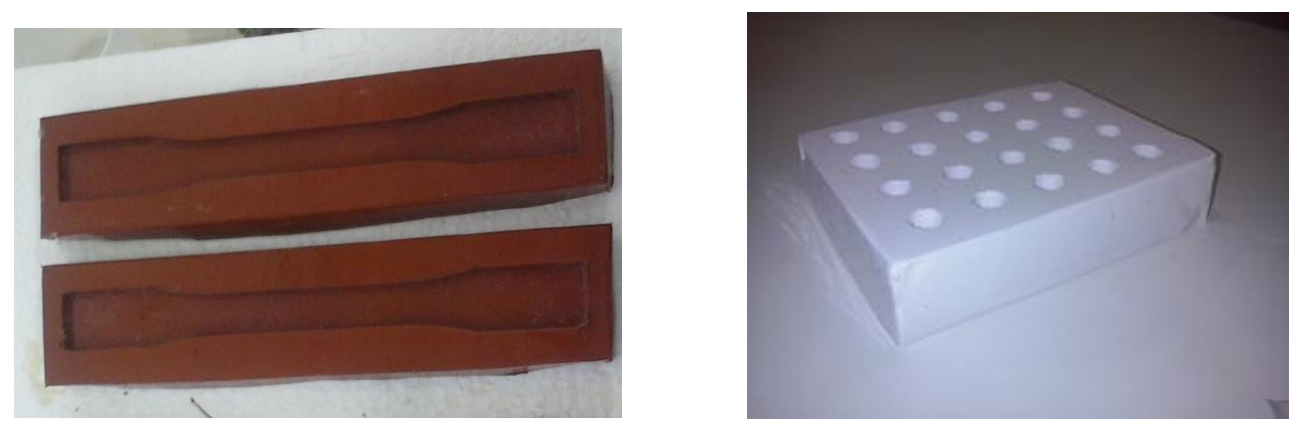

Figura 8 - Formas de silicone, utilizadas para confecções dos corpos de prova de resina epóxi, para os testes de tração e compressão respectivamente. 
Na preparação das fórmulas, foi seguida a seguinte metodologia:

1. Pesagem do endurecedor num recipiente descartável

2. Adição da quantidade de solução ácida respectiva à formulação ao endurecedor

3. Mistura manual por um minuto

4. Adição da resina à mistura de endurecedor e solução ácida.

5. Mistura manual por um minuto nas concentrações de 0,5 e $10 \%$ de solução ácida e por 3 minutos nas concentrações de solução ácida de 15, 20 e $25 \%$.

6. Deposição da mistura às formas de silicone.

É necessário que a preparação da resina seja feita dessa forma porque assim a água da solução ácida se liga nos grupos amina do endurecedor. A resina não tem boa afinidade química com a água.

\subsubsection{A capacidade de miscibilidade da resina com água}

Os estudos para verificação da capacidade de miscibilidade da resina com a água foram analisados conforme os testes mecânicos de tração e compressão, assim como, nos testes de termogravimétrica e tempo de cura.

\subsubsection{Cura ambiente}

A cura dos corpos de prova, com as concentrações de solução aquosa ácida de 0, 5 e 10\%, ocorreu em 24 horas, já para os corpos de prova com solução aquosa ácida de 15 e $20 \%$ a cura ocorreu em 48 horas. Em algumas situações, para acelerar o processo de cura utilizou-se uma estufa à $40^{\circ} \mathrm{C}$. Para os corpos de prova com $25 \%$ de solução, ocorreu a cura imparcial, portanto não foram utilizados.

\subsubsection{Ensaios de tração e compressão}

Os corpos de prova confeccionados e os ensaios de tração foram feitos segundo a norma ASTM D638-03 ${ }^{(47,48)}$, foi usada uma carga de $5 \mathrm{~kg}$ e velocidade de separação de 
$50 \mathrm{~mm} / \mathrm{min}$ até a ruptura num medidor de tração Instron modelo 5567, mostrado na Figura 9. Para cada concentração de solução aquosa ácida, especificadas na tabela 4, foram confeccionados 5 corpos de prova.

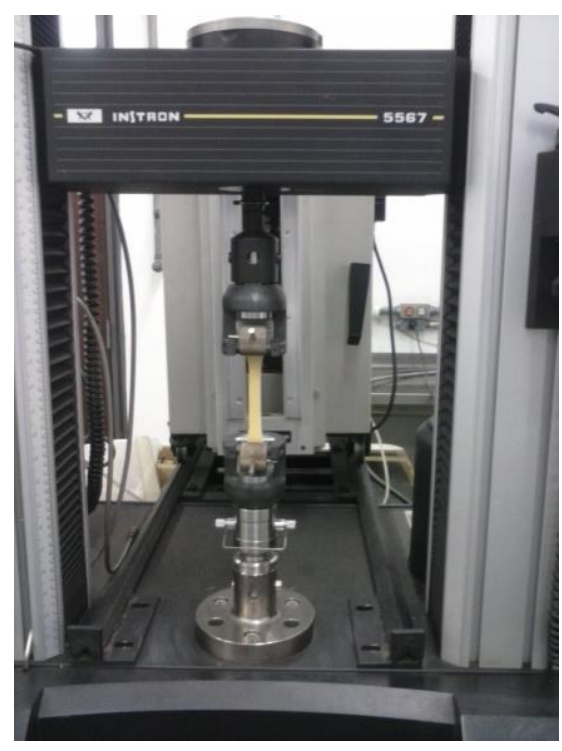

Figura 9 - Medidor de tração Instron 5567 com corpo de prova de resina epóxi rígida

Já para os ensaios de compressão os corpos de prova confeccionados foram feitos segundo a norma ASTM D695-08 ${ }^{(50)}$, foi usada uma carga de $5 \mathrm{~kg}$ e velocidade de separação de $0,8 \mathrm{~mm} / \mathrm{min}$ até a deformação num medidor de compressão Instron modelo 5567.

\subsubsection{Análise Termogravimétrica}

A análise termogravimétrica (TG) foi feita no equipamento SDT Q600 da TA Instruments. Optou-se por utilizar atmosfera de nitrogênio $\left(\mathrm{N}_{2}\right)$ para não haver oxidação da resina, com fluxo de $50 \mathrm{~mL} / \mathrm{min}$ em panela de platina. $\mathrm{O}$ aumento de temperatura foi de $10^{\circ} \mathrm{C} / \mathrm{min}$ até $700^{\circ} \mathrm{C}$. Este equipamento tem a capacidade de realizar análise termogravimétrica (TG) e calorimetria explanatória diferencial (DSC) ${ }^{(34,52)}$. Na Figura 10 é mostrado o equipamento. 


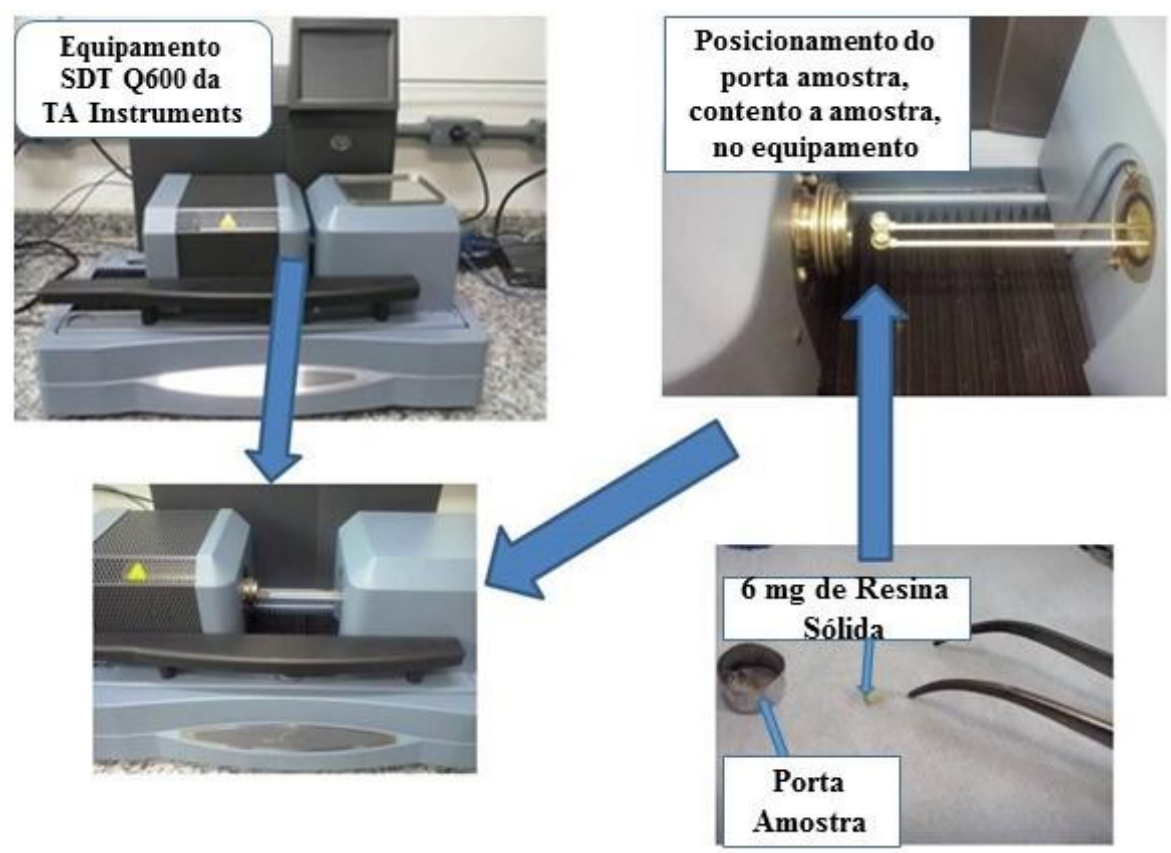

Figura 10 - Equipamento para análise termogravimétrica (TG) modelo SDT Q600

\subsubsection{Estudo da aceleração do processo de cura por radiação gama e teste mecânicos de tração}

A aceleração do processo de cura da mistura resina epóxi, endurecedor e solução aquosa ácida na concentrações de 20\%, foram conduzidas em Irradiador Multipropósito de cobalto-60 do Centro de Tecnologia das Radiações no IPEN, nas doses de 20, 40, 60, 100, 150 e $200 \mathrm{kGy}$, com taxa de dose de $6 \mathrm{kGy} / \mathrm{h}$.

Para os testes de irradiação dos corpos de prova, utilizou-se as formulações com máxima concentração de solução aquosa $20 \%$. Na Figura 11 é mostrado o esquema utilizado na irradiação das amostras. 


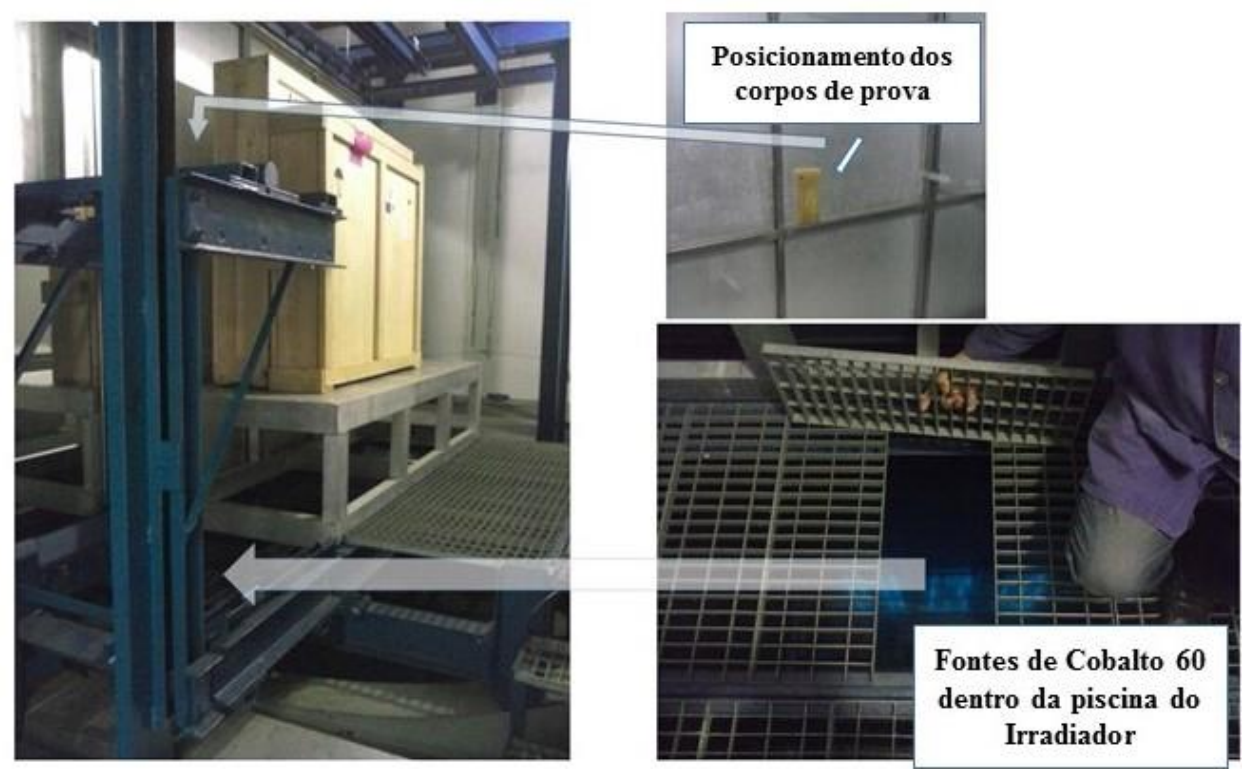

Figura 11 - Irradiador Multipropósito de Cobalto -60 do IPEN e posição em que as amostras foram irradiadas.

Na Figura 12 é mostrado os copos de prova já irradiados em diferentes doses.

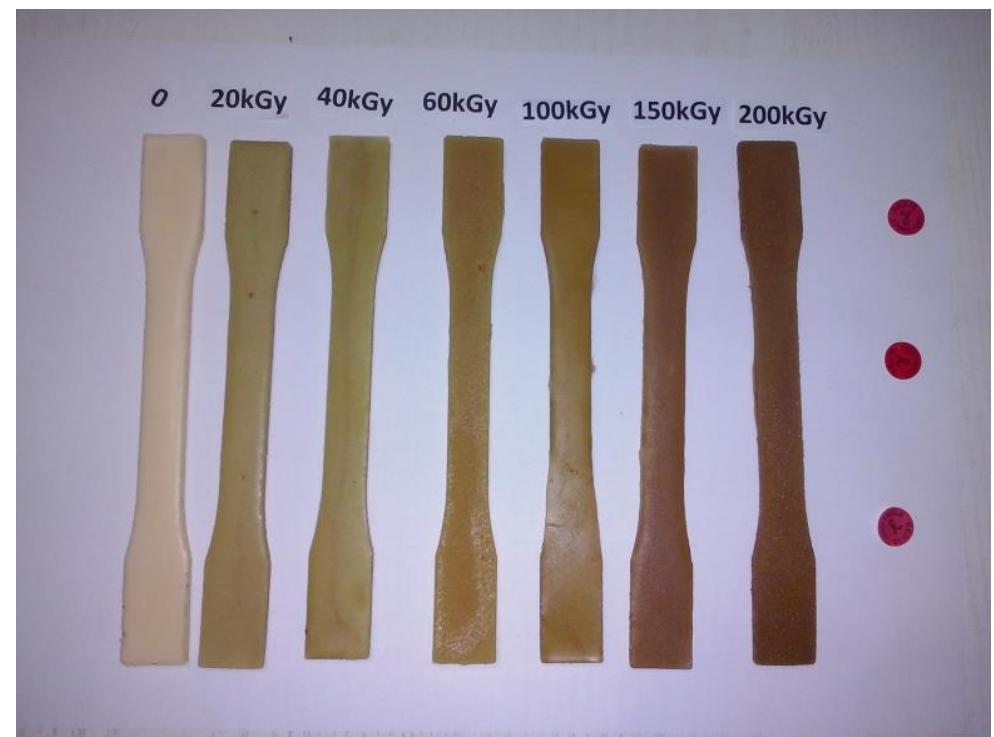

Figura 12 - Corpos de prova irradiados com as seguintes doses 0, 20, 40, 60,

$$
100,150 \text { e } 200 \mathrm{kGy} \text {. }
$$

\subsubsection{Análise termogravimétrica das amostras irradiadas}

Como foi verificado, a melhor dose de irradiação ficou em torno de $33 \mathrm{kGy}$, foi feita a análise térmica apenas das amostras que foram irradiadas com 20 e $40 \mathrm{kGy}$, para que pudessem ser comparadas com a amostra sem irradiação. Lembrando que os testes 
foram realizados utilizando a formulação com o teor máximo de solução aquosa ácida de $20 \%$.

\subsection{Produção das fontes de calibração}

Não foi possível confeccionar uma fonte de ${ }^{57} \mathrm{Co}$, pois não tínhamos disponível a solução radioativa, porém as soluções radioativas são importadas da empresa alemã Eckert \& Ziegler Isotope Products $(E \& Z)$ e vêm em soluções padrão de $1 \mathrm{ml}$ com atividade de 5mCi. Portanto, se fossemos confeccionar uma fonte de Cobalto utilizaríamos $1 \mathrm{ml}$ para obtermos a atividade desejada de $185 \mathrm{MBq}$, como sugeri as normas.

Na Figura 13 é mostrada, como exemplo, a ampola padrão da solução radioativa de bário-133 importada da empresa Eckert \& Ziegler, contento $1 \mathrm{ml}$ de solução radioativa com atividade de $5 \mathrm{mCi}$, as de Césio -137 e Cobalto-57 vêm na mesma quantidade.

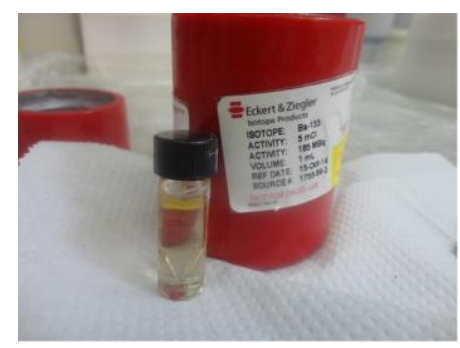

Figura 13 - Ampola da solução radioativa de bário-133 importada da empresa Eckert \& Ziegler

Na Figura 14 são mostradas as fontes de césio- 137 e bário-133, com atividade respectivamente de 7,86 e 8,90 MBq, produzidas neste trabalho.

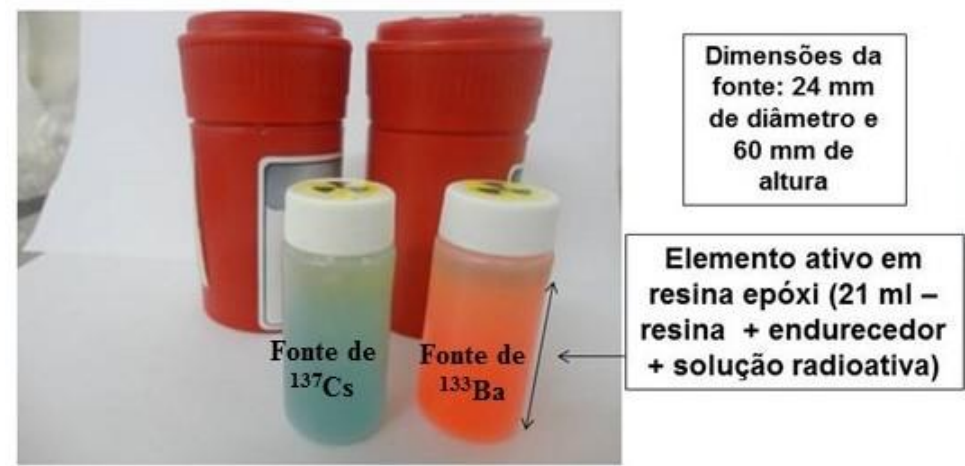

Figura 14 - Fontes seladas de Césio-137 e Bário-133, produzidas neste trabalho 
A produção dessas fontes já é realizada no IPEN, os materiais e métodos são os seguintes:

Os frascos nos quais a fonte será confeccionada, são frascos padrão de polietileno com volume máximo de $26 \mathrm{ml}$. Foi colocada fita adesiva transparente ao redor do frasco e são encapados com papel filme para evitar a contaminação. A seguir preparam-se os castelos de chumbo, forrando a parte interna com papel filme. Após, pipeta-se no frasco um certo volume de material radioativo (valores para as fontes de bário e césio especificados na Tabela 5) e mede-se a atividade utilizando o detector câmara de ionização Capintec modelo-15R.

Tabela 5 - Quantidades de material radioativo utilizado para a confecção de fontes e medição da atividade

\begin{tabular}{|c|c|c|c|c|}
\hline Fonte & $\begin{array}{c}\text { Quantidade } \\
\text { de solução } \\
\text { radioativa( } \mu \mathrm{l})\end{array}$ & $\begin{array}{c}\text { Atividade } \\
\text { Medida } \\
(\mathrm{MBq})\end{array}$ & $\begin{array}{c}\text { Quantidade de } \\
(\text { Resina+endurecedor })\end{array}$ & $\begin{array}{c}\text { Porcentagem que a } \\
\text { solução radioativa } \\
\text { representa na } \\
\text { mistura }\end{array}$ \\
\hline${ }^{57} \mathrm{Co}$ & 1000 & --- & $21 \mathrm{ml}$ & $5 \%$ \\
\hline${ }^{133} \mathrm{Ba}$ & $\mathbf{5 0}$ & $\mathbf{8 , 9}$ & $21 \mathrm{ml}$ & $<1 \%$ \\
\hline${ }^{137} \mathrm{Cs}$ & 40 & 7,86 & $21 \mathrm{ml}$ & $<1 \%$ \\
\hline
\end{tabular}

Após o ajuste da atividade desejada, coloca-se o frasco em uma balança medindo a quantidade de endurecedor (em torno de $3,5 \mathrm{ml}$ ), a mistura de endurecedor mais solução radioativa, é feita manualmente por volta de um minuto, após esse processo acrescentase a resina com corante (em torno de $17,5 \mathrm{ml}$ ). A mistura é feita manualmente por volta de 1 min.

Estando a fonte pronta, espera-se a mistura curar a temperatura ambiente, por volta de 48 horas. Antes de fechar com a tampa, prepara-se uma pequena quantidade de resina mais endurecedor e preenche o restante do recipiente, para mantê-la mais segura, após esse processo a fonte é fechada. O corante em pó adicionado na resina epóxi, antes de acrescentar o endurecedor mais solução radioativa, é importante para a visualização da homogeneidade da mistura após adicionar esses elementos. Para a fonte de Bário-133 
foi utilizado corante laranja e para a fonte de Cs-137 corante azul. Na Figura 15 é mostrado o processo de produção, onde:

$\mathrm{A}=$ frasco padrão de polietileno; $\mathrm{B}=$ castelo de chumbo, onde será confeccionada a fonte e par posterior armazenamento; $\mathrm{C}=$ frasco dentro do castelo de chumbo (ambos embalados externamente para evitar contaminação) em um suporte; D = ampola contendo a solução radioativa $; \mathrm{E}$ = endurecedor e resina epóxi (com corante); $F=$ pipetando o material radioativo no frasco (já contém o endurecedor); $G=$ fonte já contendo a resina, o endurecedor e a solução radioativa); $\mathrm{H}=$ fonte sem tampa contendo uma adição de resina pura com o endurecedor; $\mathrm{I}=$ fronte fechada e $\mathrm{J}=$ Fonte selada de bário-133 pronta para uso.
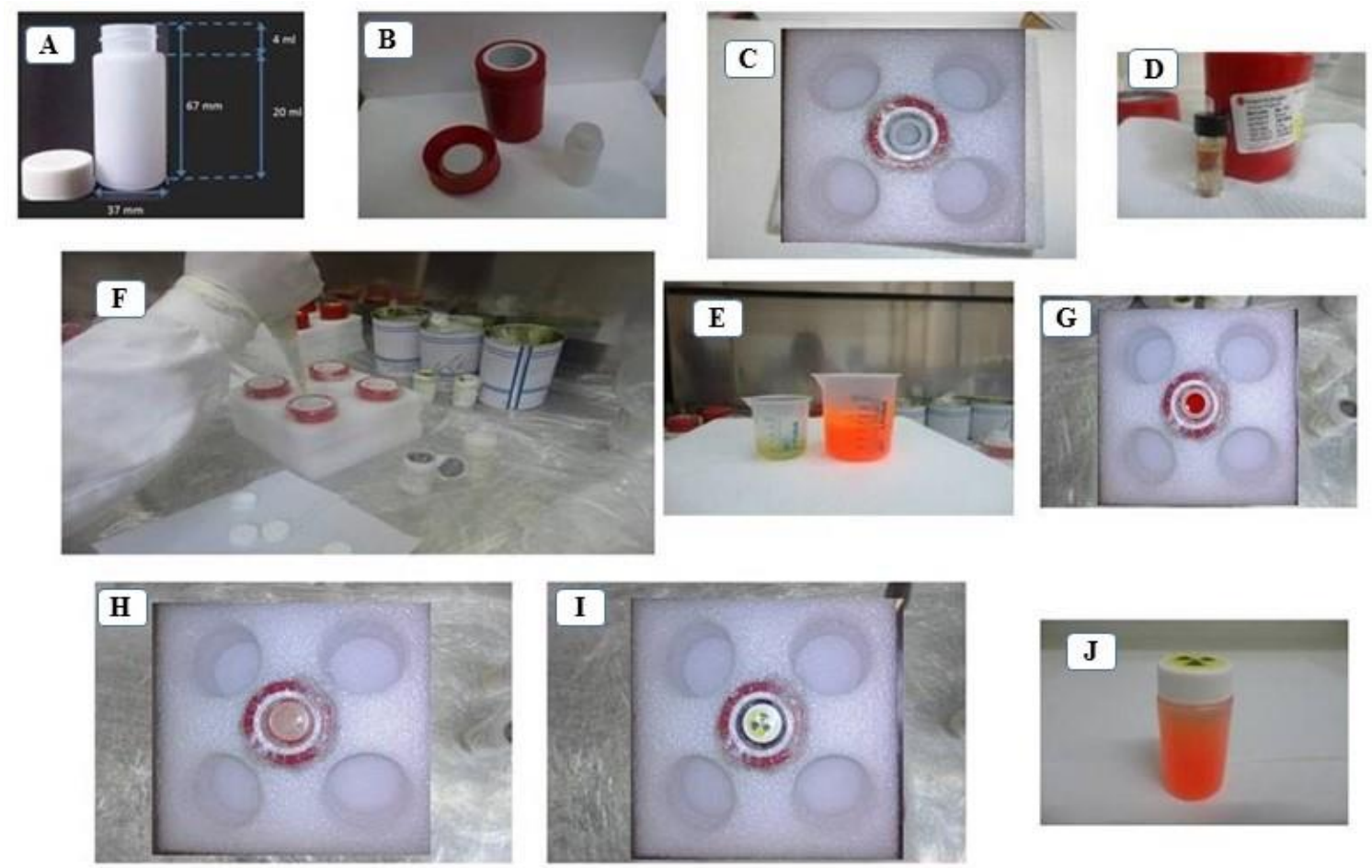

Figura 15 - Etapas da confecção da fonte de ${ }^{133} \mathrm{Ba}$ imobilizada em resina epóxi

Para a confecção da fonte de Cs-137 o procedimento foi o mesmo, mudando apenas a quantidade de solução radioativa. Na Figura 16 é mostrada a fonte de Césio 137 produzida. 


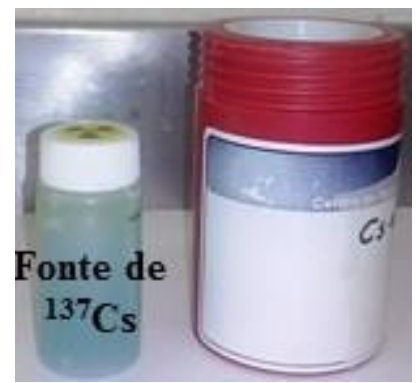

Figura 16 - Fonte produzida de Cs -137 imobilizada em resina epóxi

Apenas as fontes de césio e bário foram confeccionadas, as atividades foram medidas utilizando câmara de ionização do fabricante Capintec modelo CRC-15R.

\subsection{Execução dos testes de estanqueidade normalizados pela norma "International Standard Organization Radiation protection - leakage test methods" ISO 9978}

De acordo com a norma ISO 9978 as fontes radioativas sólidas de ${ }^{57} \mathrm{Co},{ }^{137} \mathrm{Cs}$ e ${ }^{133} \mathrm{Ba}$ pertencem à classificação "A" (fontes seladas contendo material radioativo). Para avaliar o vazamento das fontes a norma sugere testes de imersão em líquido quente, fervente, frio, à temperatura ambiente e cintilador. Também sugere teste de hélio, bolhas e esfregaço ${ }^{(31)}$.

Para este trabalho, foram escolhidos os testes de esfregaço e os testes de imersão à temperatura ambiente e a líquido quente à $70^{\circ} \mathrm{C}$.

\subsubsection{Teste de esfregaço}

Na Figura 17 é mostrada a fonte de césio-137 utilizada para o teste de esfregaço.

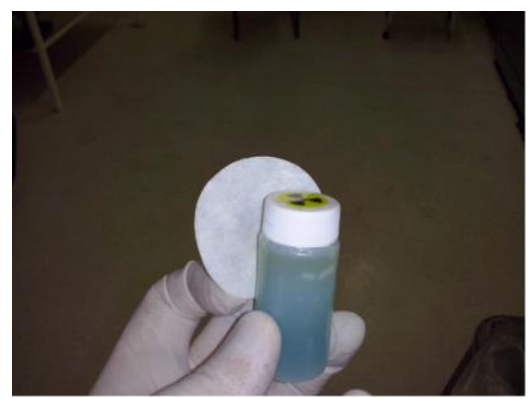

Figura 17 - Esfregaço com papel absorvente da fonte de Césio-137 
Foram realizados os testes de esfregaço a úmido ${ }^{(32)}$. As fontes confeccionadas de bário e césio foram utilizadas para o teste, o esfregaço foi feito com um pedaço de papel absorvente umedecido com detergente Extran. Este papel foi esfregado na superfície e tampa dos frascos das duas fontes. O papel teve sua atividade medida (antes e depois), para as medições das atividades do papel antes e após o esfregaço, foi utilizado um detector de iodeto de sódio tipo poço do fabricante Capintec modelo CRC -15W foi possui sensibilidade maior. Na figura 18 é mostrado o equipamento ligado ao detector de iodeto de sódio com tálio - $\mathrm{NaI}(\mathrm{Tl})$.

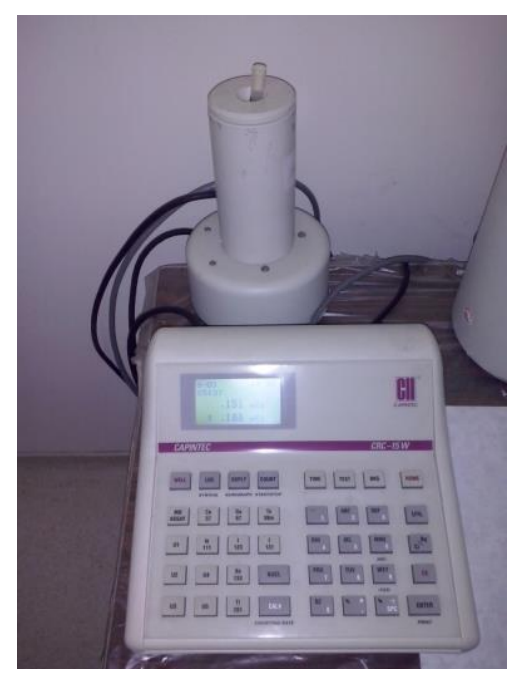

Figura 18 - Detector de iodeto de sódio modelo CRC-15W

\subsubsection{Teste de imersão à temperatura ambiente e teste de imersão a líquido quente à $70^{\circ} \mathrm{C}$}

As fontes confeccionadas de bário e césio, foram submetidas separadamente ao teste de imersão à temperatura ambiente. Elas foram colocadas em um béquer contendo 250 $\mathrm{mL}$ de água destilada a $25^{\circ} \mathrm{C} \pm 5^{\circ} \mathrm{C}$. $\mathrm{O}$ béquer com as fontes permaneceu em banho termostático por 24 horas. Parâmetros estes de acordo com a norma ISO 9978. Na Figura 19 é mostrado o esquema utilizado para o teste ${ }^{(32)}$. 


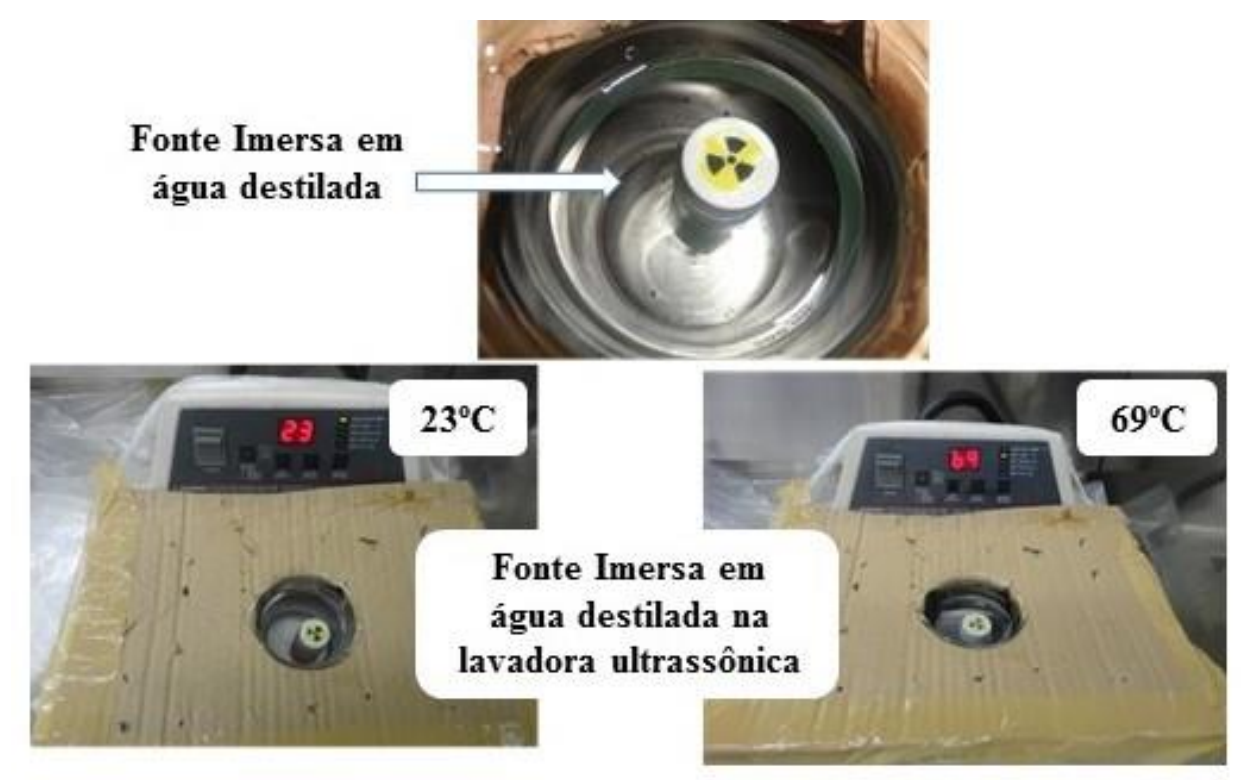

Figura 19 - Fonte imersa em água destilada para os testes de estanqueidade

Para os testes de imersão em líquido quente a $70^{\circ} \mathrm{C}$, as fontes foram colocadas em um béquer contendo $250 \mathrm{~mL}$ de água destilada a $70^{\circ} \mathrm{C} \pm 5^{\circ} \mathrm{C}$. O béquer com as fontes permaneceu em banho em uma lavadora ultrassônica por 30 minutos com aplicação simultânea de ultrassom durante todo o período de imersão para garantir a remoção total de material radioativo se existir ${ }^{(32)}$.

Após o tempo de 24 horas no caso da temperatura ambiente e 30 minutos no caso da imersão à $70^{\circ} \mathrm{C}$, as fontes foram retiradas e secas com papel absorvente. Toda a água utilizada no teste foi colocada nos frascos de polietileno de $26 \mathrm{ml}$ e uma alíquota foi colocada em tudo de ensaio com rolha. O papel utilizado na secagem das fontes, os frascos de $26 \mathrm{ml}$, o tudo de ensaio e amostra de água destilada retiradas antes do teste e depois, foram medidas no detector de radiação Capintec modelo $\mathrm{CRC}-15 \mathrm{~W}$, iodeto de sódio tipo poço.

\section{RESULTADOS E DISCUSSÃO}

\subsection{Resultados dos estudos da exatidão e precisão dos ativimetros disponíveis no CTR}

Na Tabela 6 é mostrada as medidas realizadas nos ativímetros modelo Capintec CRC 15R e CRC -15W (câmaras de ionização). 
Tabela 6 - Testes de precisão e exatidão.

\begin{tabular}{|c|c|c|c|}
\hline Fontes Importadas & ${ }^{\mathbf{5}} \mathbf{C o}$ & ${ }^{\mathbf{1 3 3}} \mathbf{B a}$ & ${ }^{\mathbf{1 3 7}} \mathbf{C s}$ \\
\hline Teste de precisão utilizando CRC- 15 R & $0,46 \%$ & $0,26 \%$ & $0,32 \%$ \\
\hline Teste de exatidão utilizando CRC-15R & $1,23 \%$ & $0,61 \%$ & $3,2 \%$ \\
\hline Teste de precisão utilizando CRC- 15 W & $0,46 \%$ & $0,63 \%$ & $0,43 \%$ \\
\hline Teste de exatidão utilizando CRC-15W & $1,62 \%$ & 1,22 & $3,65 \%$ \\
\hline
\end{tabular}

Os testes de exatidão e precisão realizados com medidor de atividade mostraram-se dentro dos parâmetros estabelecidos na norma CNEN-NN-3.05, garantindo assim as confiabilidades desejadas de 90 e $95 \%$ para exatidão e precisão ${ }^{(24)}$.

Para a precisão: o limite de aceitação é de $\pm 5 \%$ com confiabilidade de $95 \%$ recomendado pela norma da CNEN. Os valores obtidos nos ensaios foram satisfatórios não ultrapassando o limite recomendado ${ }^{(24)}$.

Já para a Exatidão: o limite de aceitação é de $\pm 10 \%$ com confiabilidade de $90 \%$ recomendado pela norma da CNEN. Os valores obtidos nos ensaios foram satisfatórios não ultrapassando o limite recomendado ${ }^{(24)}$.

\subsection{Resultados do estudo das propriedades da resina epóxi curada.}

\subsubsection{Capacidade de cura ambiente da miscibilidade da resina com água}

A adição de água na mistura resina epóxi-endurecedor não afeta o tempo de cura ambiente que dura entre 24 e 48 horas, como é mostrado na Tabela 7, desde que não seja ultrapassada mais de $20 \%$ em massa em água ao sistema epóxi. Quantidades superiores a $20 \%$ em massa conduzem desde a cura parcial originando regiões de polimerização descontinuada, esse fato foi observado nas amostras com $25 \%$ de solução ácida que foram preparadas. 
Tabela 7 - Tempo de cura ambiente das formulações.

\begin{tabular}{|c|c|c|}
\hline Formulações & Tempo de Cura & Estufa $\left(\mathbf{4 0}^{\circ} \mathbf{C}\right)$ \\
\hline 0 & $24 \mathrm{~h}$ & ---- \\
\hline $5 \%$ & $24 \mathrm{~h}$ & ---- \\
\hline $10 \%$ & $24 \mathrm{~h}$ & --- \\
\hline $15 \%$ & $48 \mathrm{~h}$ & $24 \mathrm{~h}$ \\
\hline $20 \%$ & $48 \mathrm{~h}$ & $24 \mathrm{~h}$ \\
\hline $25 \%$ & ----- & ------ \\
\hline
\end{tabular}

\subsubsection{Resultados dos ensaios de tração}

Na Figura 20 são mostrados os corpos de prova já curados e o ensaio realizado em Instron. Já na Figura 21 são mostrados os copos de prova após os testes de tração.
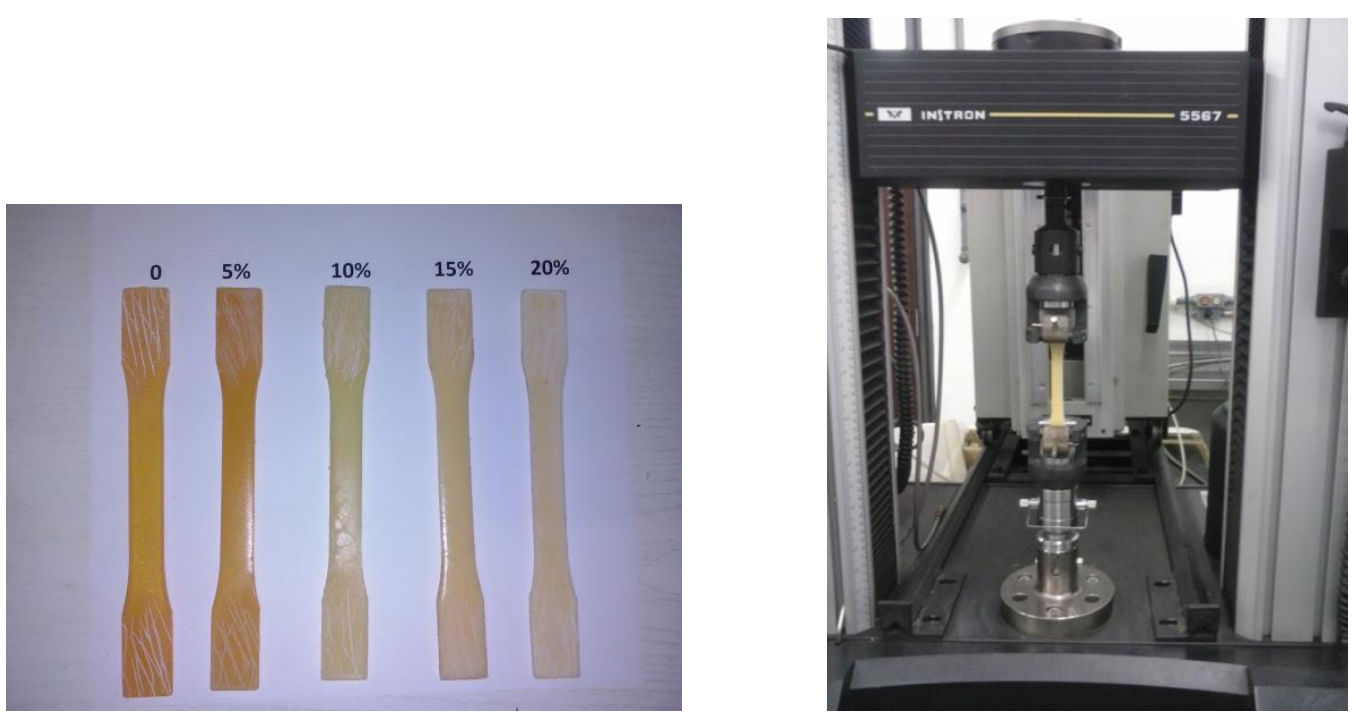

Figura 20 - Copos de prova de resina epóxi com diferentes concentrações de solução radioativa e teste de tração realizado em Instron. 


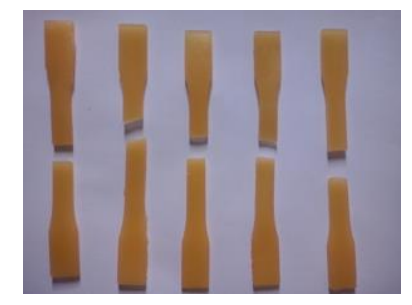

Figura 21 - Corpos de Prova após teste de tração.

Na Figura 22 é mostrada a curva de resistência à tração que os corpos de prova exerceram ao serem estirados no equipamento em função a porcentagem de água adicionada à formulação, cada ponto representado no gráfico é a média dos valores da grandeza analisada com seu respectivo desvio padrão dos testes dos cinco corpos de prova para cada formulação.

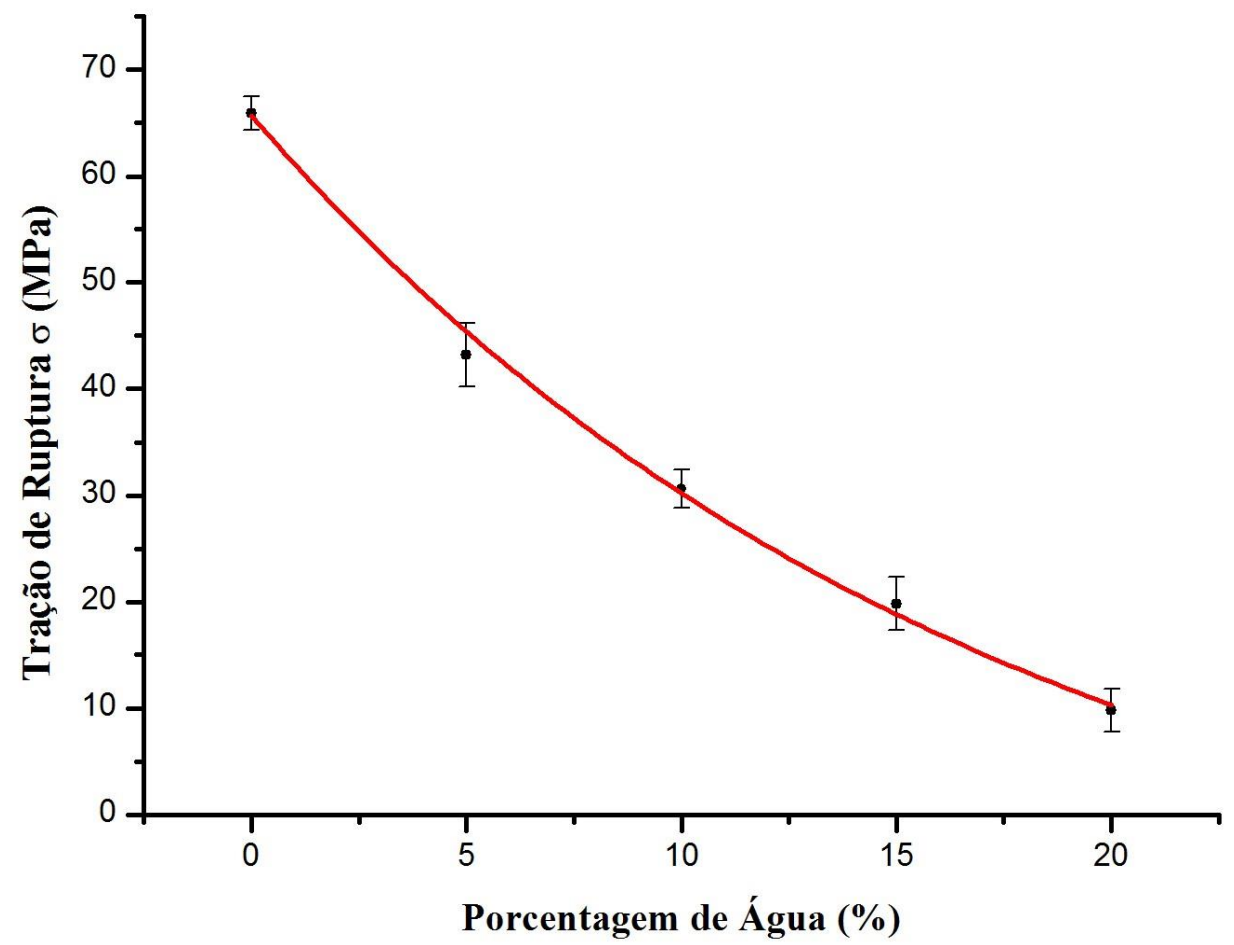

Figura 22 - Curva da Tração de Ruptura em função da porcentagem de água

Verificou-se que a diminuição da resistência do material frente a adição de água na composição de cura pode ser explicado pela perda de propriedades plásticas devido ao aumento da cristalinidade que ocorre neste processo, visto que a elongação do material passa ser constante a partir de 5\% em água como é mostrada na Figura 23, a seguir na 
qual é representada a elongação dos corpos de prova, durante o ensaio de resistência a tração, em função da porcentagem de água adicionada a mistura epóxi-catalisado.

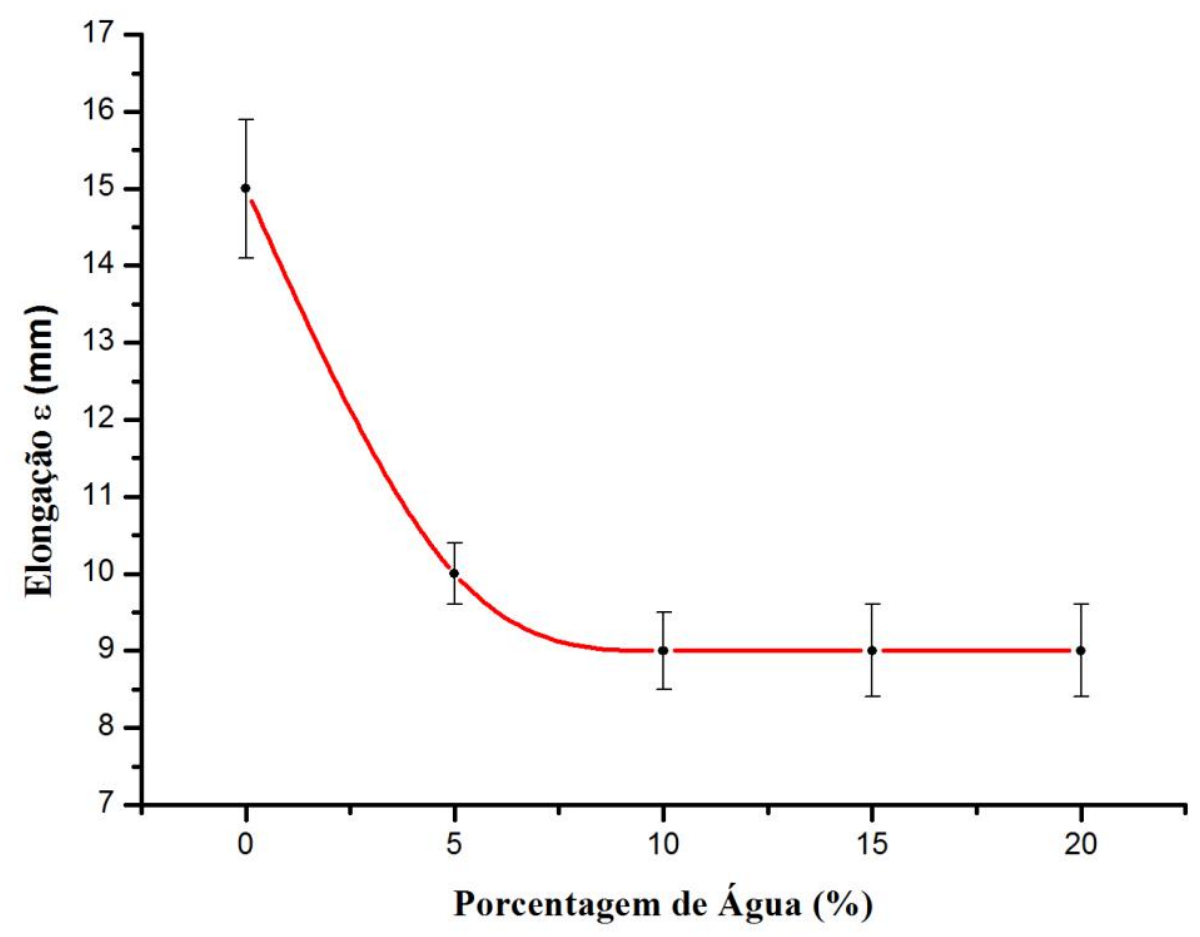

Figura 23 - Curva elongação em função da porcentagem de água.

\subsubsection{Resultados dos ensaios de compressão}

Na Figura 24 são mostrados os corpos de prova já curados e o ensaio na Instron. Já na Figura 25 é mostrado o corpo de prova após o ensaio de compressão.

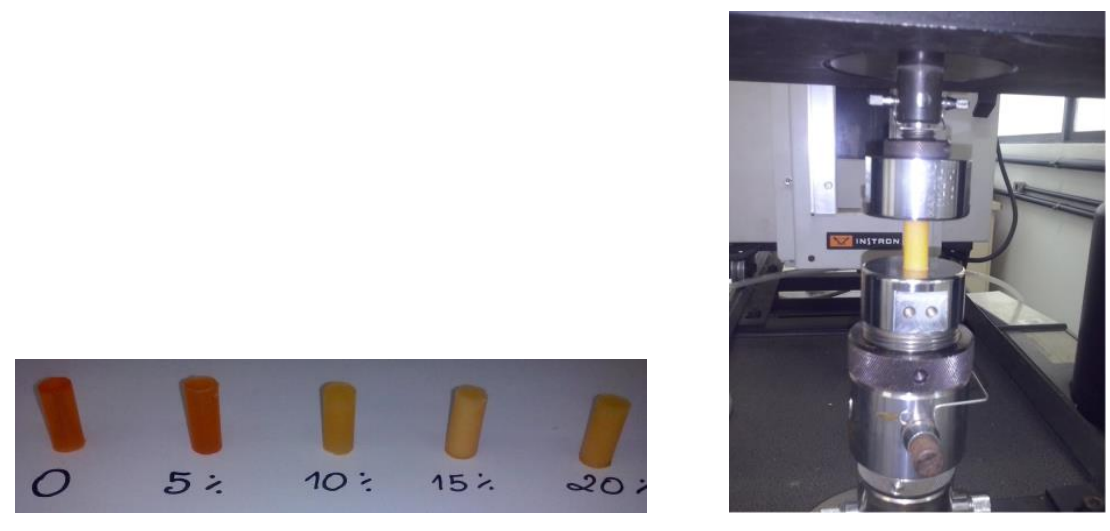

Figura 24 - Copos de prova de resina epóxi com diferentes concentrações de solução radioativa e teste de compressão realizado em Instron 


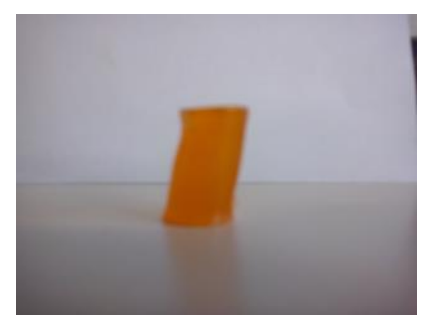

Figura 25 - Corpo de prova após ensaio de compressão.

Nota-se, como é mostrado na Figura 26, que assim como na tração, a adição de água diminui à resistência mecânica do material à compressão.

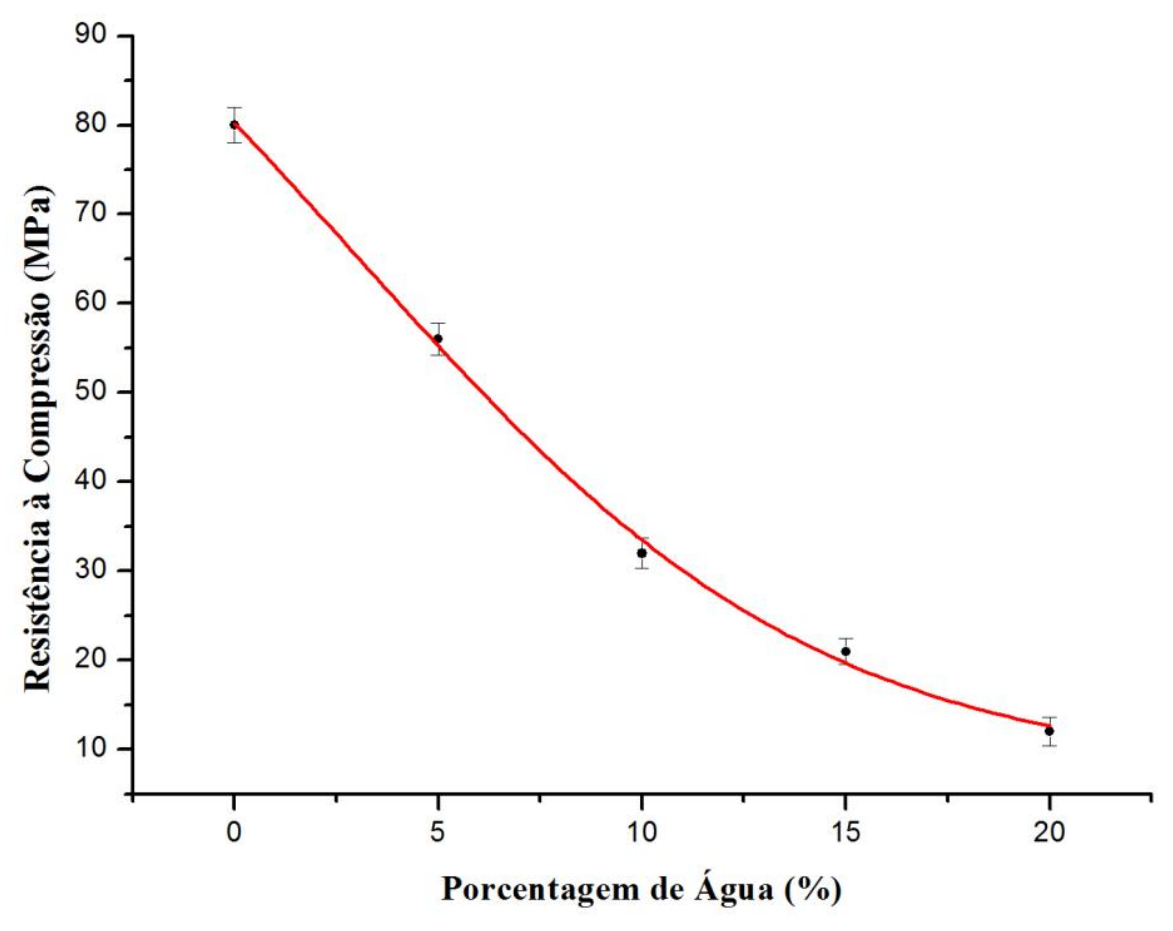

Figura 26 - Curva da resistência à Compressão em função da porcentagem de água

Tanto nos testes de compressão quanto nos testes de tração, a resina apresentou altos valores de resistência, sendo que a resistência à compressão apresentou valores superiores a $50 \mathrm{MPa}$ (o valor que interessa, pois o máximo que se usa de solução radioativa na produção dessas fontes é de $5 \%$ ). 
Nos testes de tração e compressão, verificou-se a diminuição da resistência do material frente a adição de água na composição, porém para aplicação na fabricação de fontes de verificação, o máximo que se usa é de $5 \%$ de solução radioativa, apresentando valores de forças tensão e compressão ainda elevados.

\subsubsection{Resultados do estudo da aceleração do processo de cura por radiação gama e Teste mecânicos e térmicos da resina curada}

Na Figura 27 são mostrados os testes de tração realizados com copos de prova de resina irradiados em diferentes doses.

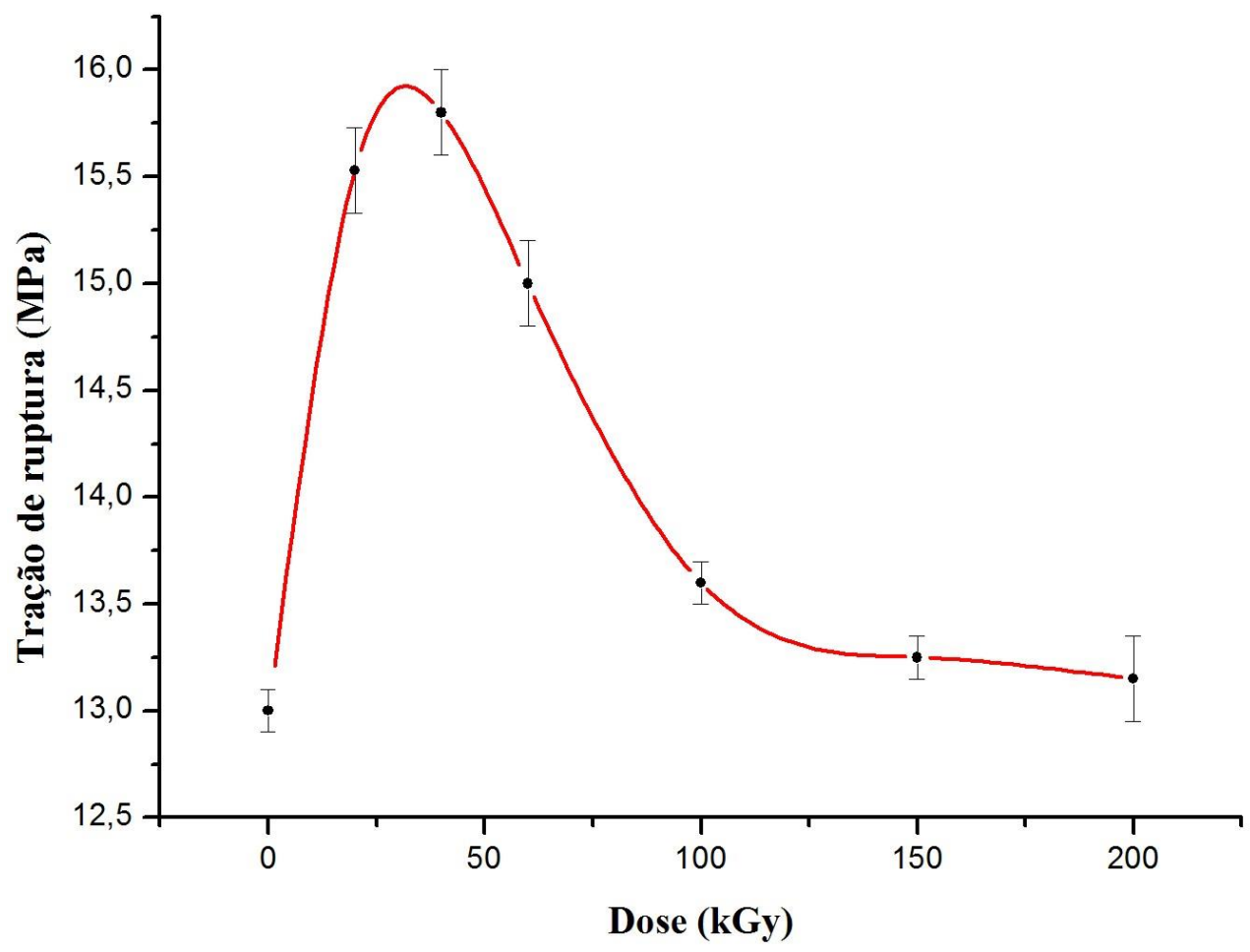

Figura 27 - Curva de Tração de Ruptura em função da dose recebida.

Na Figura 28 são mostrados os testes de compressão realizados com copos de prova de resina irradiados em diferentes doses. 


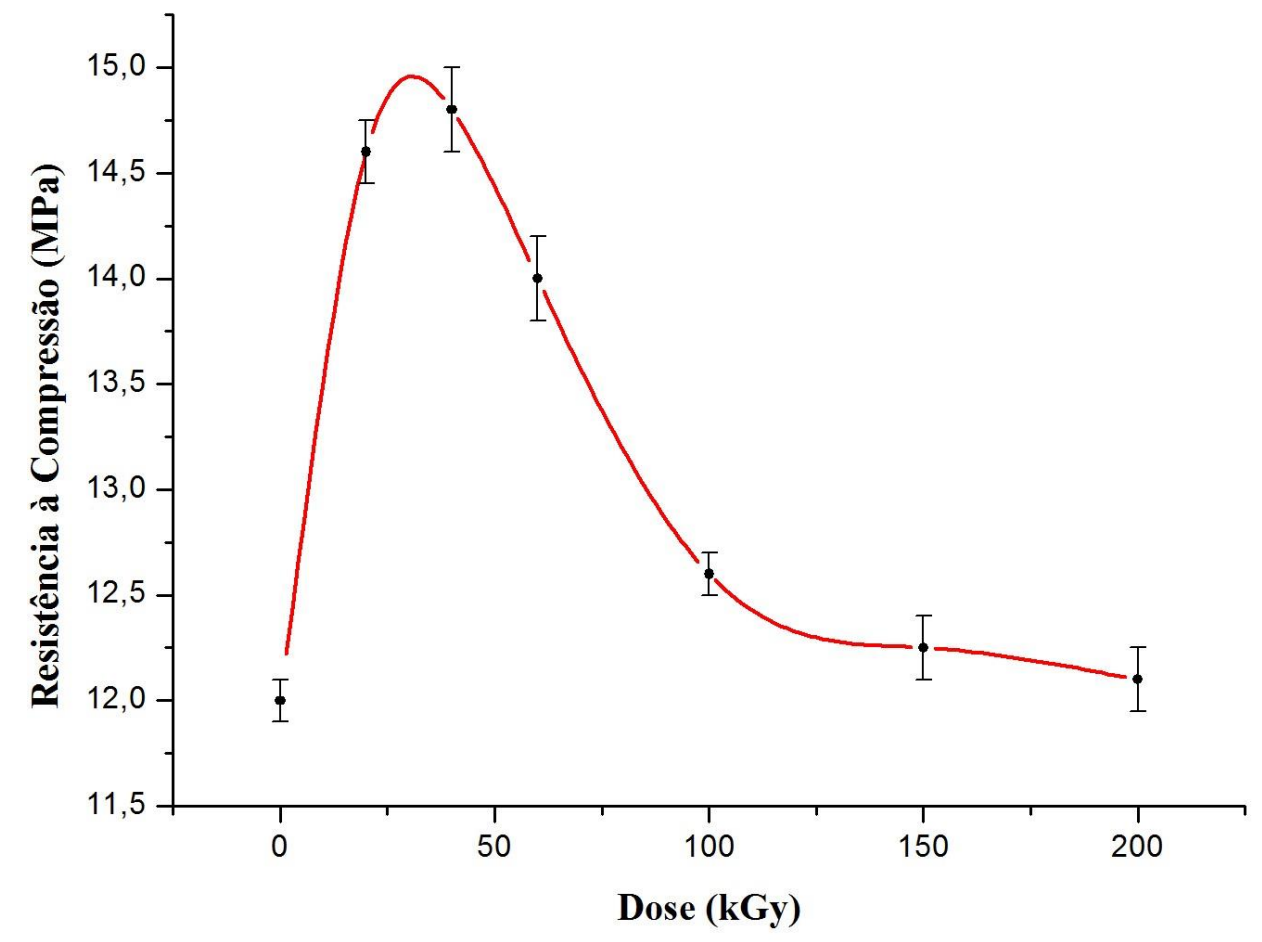

Figura 28 - Curva de resistência à compressão em função da dose recebida.

Nota-se, após o ensaio de resistência a tração e a compressão, que a irradiação possibilita o aumento da resistência mecânica até ao redor de uma dose de $33 \mathrm{kGy}$ para tração e 30 kGy para compressão, a partir da qual se observa um processo inverso, ou seja, uma redução da resistência a tração até atingir um patamar próximo a 200kGy onde parece existir uma constância na resistência a tração, mas superior a inicial sem ser submetida a dose qualquer.

O aumento da resistência até a dose de $33 \mathrm{kGy}$ deve estar associada a formação de ligações cruzadas adicionais aos do material polimerizado a cura ambiente, por outro lado, a redução da resistência até ao redor de $150 \mathrm{kGy}$ seja devido ao rompimento de algumas ligações cruzadas. A partir de $150 \mathrm{kGy}$, o patamar para resistência superior a inicial mas inferior a doses até $33 \mathrm{kGy}$ ocorre portanto associado a uma estabilização na ruptura de ligações.

A água adicionada a composição da matriz epóxi é totalmente incorporada a estrutura do polímero já que não se verificou qualquer alteração significativa de sua densidade durante a irradiação, como é mostrada na Figura 29. 


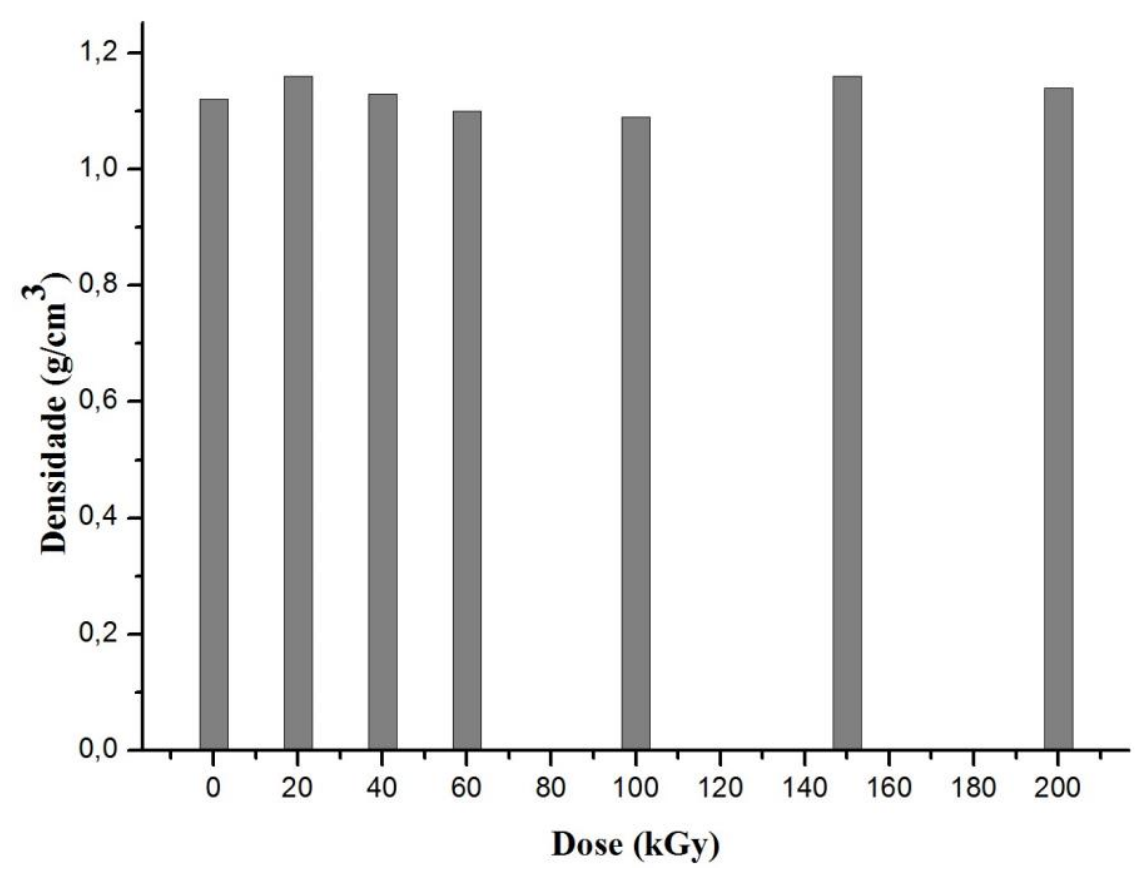

Figura 29 - Densidade da resina em função da dose recebida.

\subsubsection{Resultados da Análise Termogravimétrica}

Os objetivos iniciais da análise termogravimétrica era investigar à partir de qual temperatura a resina começaria a decompor e também a possível evaporação da água durante o aumento da temperatura realizado pela análise em si. Essa evaporação estaria relacionada a perda de material radioativo da fonte, caso algum volume significativo de água evaporasse próximo a temperatura de ebulição da água.

Investigou-se então a perda de massa de amostras feitas com as formulações dos testes de tração e compressão, comparando com a perda da resina sem a adição de água (O\%). Na Figura 30, são mostradas as curvas obtidas na análise termogravimétrica.

Analisando a Figura 30, podemos verificar que as temperaturas iniciais de decomposição para todas as amostras apresentaram praticamente o mesmo valor e as perdas de massa no início apresentaram valores próximos comparados com a resina pura sem adição de água. Não houve diferença proporcional inicial às concentrações de solução ácida adicionada às formulações. A água adicionada está quimicamente ligada à matriz em todas as formulações e portanto se mostra estanque à elevações de temperatura até por volta $280{ }^{\circ} \mathrm{C}$. Ocorreu apenas um pequeno deslocamento da 
temperatura final de decomposição. Observa-se também que a decomposição inicia-se à uma temperatura em torno de $300{ }^{\circ} \mathrm{C}$, como é mostrada na Figura 31, ocorrendo uma pequeno deslocamento dessa temperatura dependendo da concentração de solução aquosa. As fontes de verificação, em condições normais não atingirão essa temperatura, pois encontram-se estocadas em temperatura ambiente ou ambiente refrigerado.

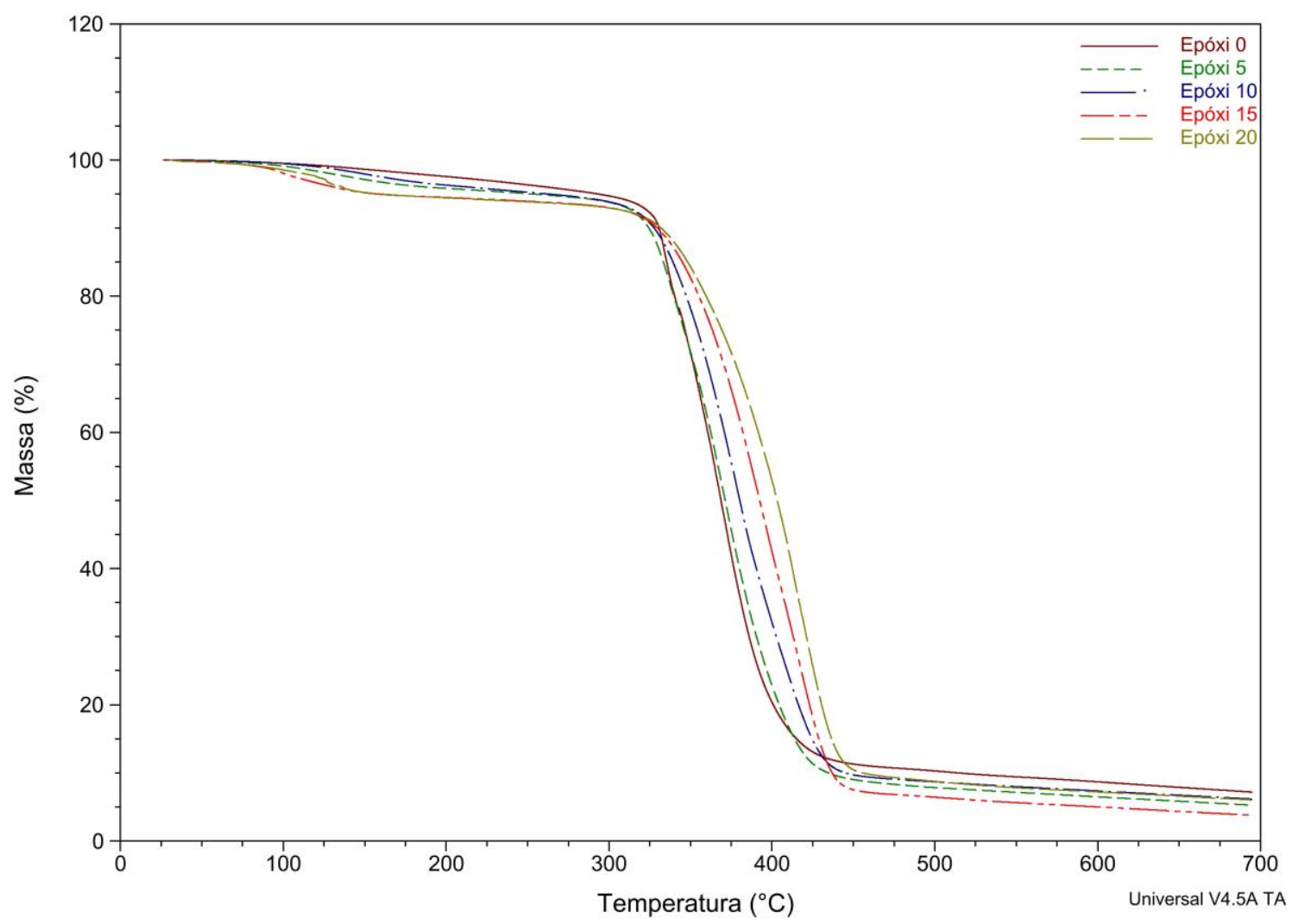

Figura 30 - Perda de massa em função da temperatura, para amostras de diferentes porcentagens de solução ácida $(0-20 \%)$ em peso da resina mais endurecedor 


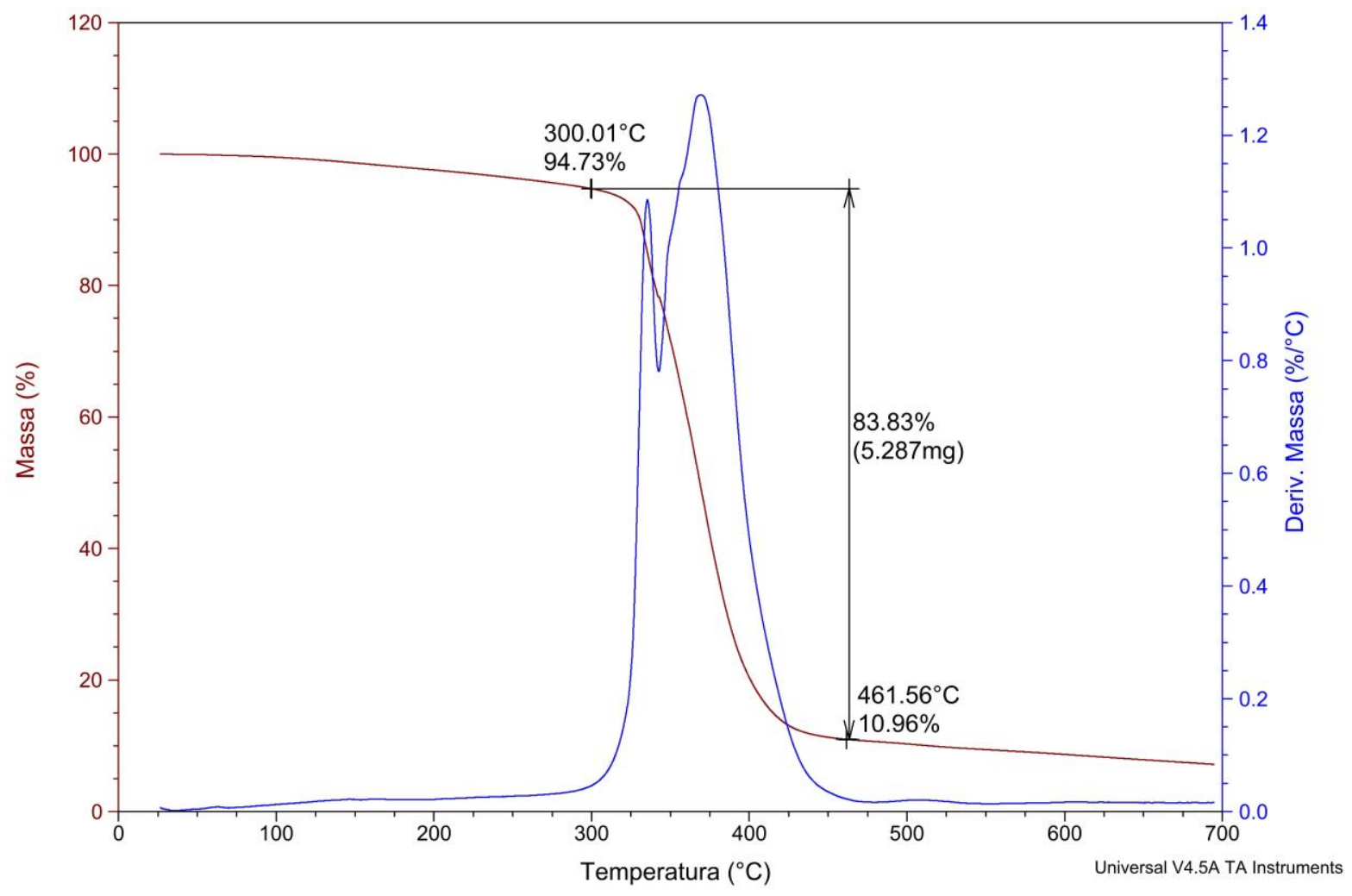

Figura 31 - Perda de massa da resina pura mais endurecedor em função da temperatura sem adição da solução ácida

\subsubsection{Resultado da análise termogravimétrica das amostras irradiadas}

Na Figura 32 são mostradas as curvas termogravimétricas da amostra sem irradiação e as irradiadas com as doses de $20 \mathrm{kGy}$ e $40 \mathrm{kGy}$, evidenciando as temperaturas iniciais e finais de decomposição. Podemos notar um pequeno deslocamento da temperatura inicial para valores maiores de decomposição, evidenciando pouca melhoria nas propriedades térmicas da resina. Notamos também, que a perda de massa, no início comparando as curvas, é constante. A média da temperatura inicial continuou em torno de $300^{\circ} \mathrm{C}$. 


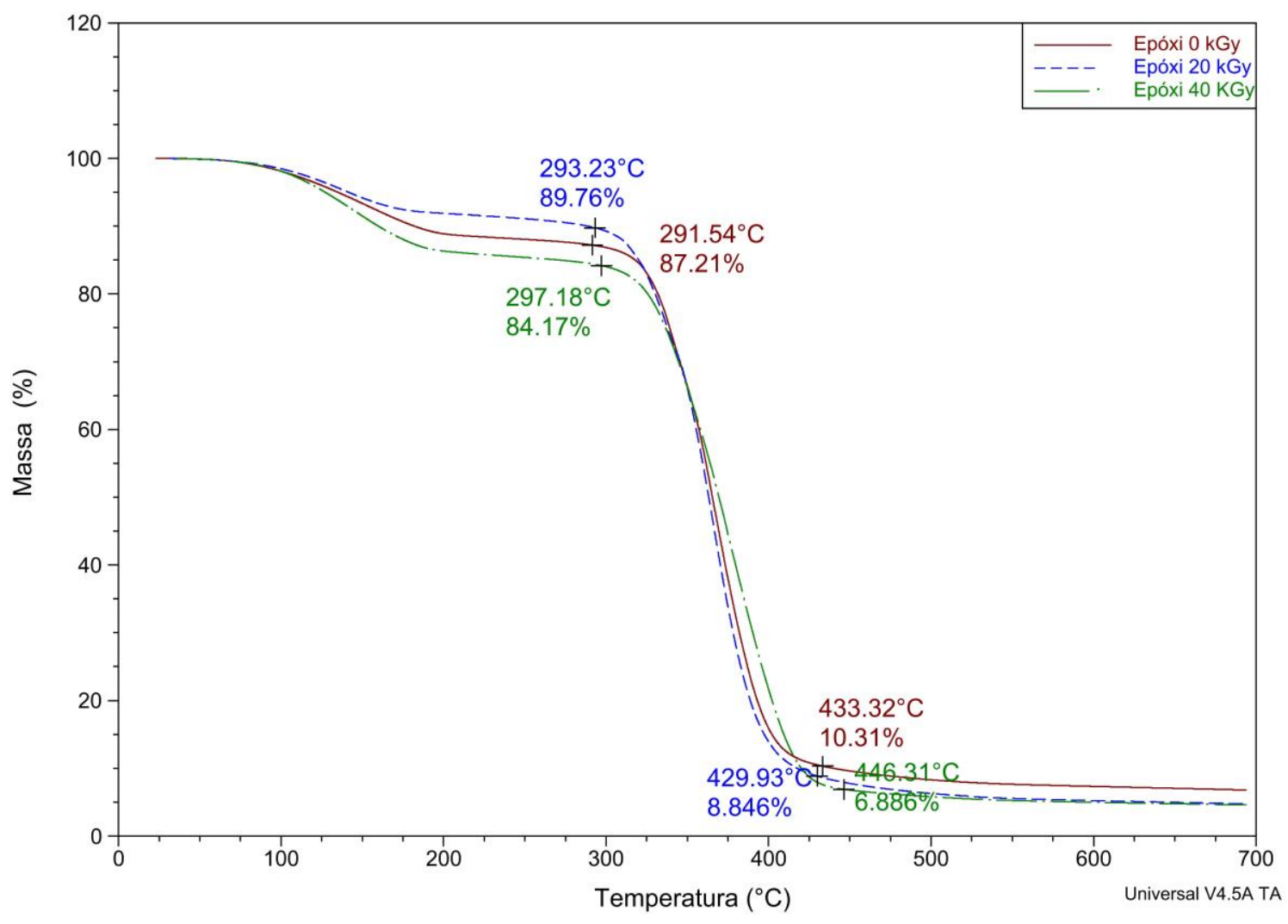

Figura 32 - Curvas termogravimétricas das amostras sem irradiação e das irradiadas com as doses de $20 \mathrm{kGy}$ e $40 \mathrm{kGy}$

5.3 Resultados da homogeneidade das fontes produzidas de bário e césio seladas com resina epóxi

\subsubsection{Teste da distribuição da resina mais endurecedor}

Na Figura 33 é mostrado alguns testes de quantidades de resina mais endurecedor e verificação da sua homogeneidade no frasco. Para a quantidade escolhida de $21 \mathrm{ml}$ (resina mais endurecedor) junto com a solução aquosa (menores que $5 \%$ ), obtivemos uma homogeneidade melhor, representada no frasco com a resina cor laranja. 


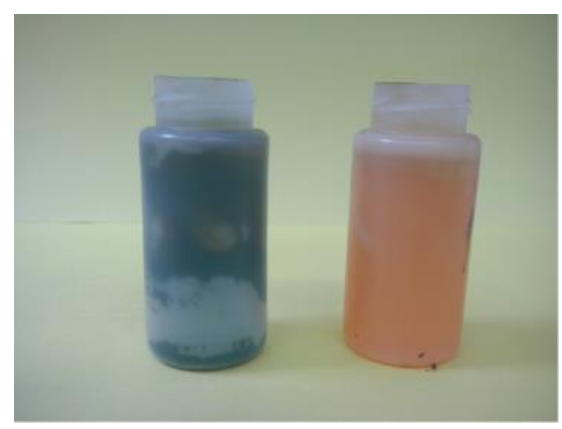

Figura 33 - Verificação da homogeneidade da resina no frasco da fonte.

\subsubsection{Medição da atividade das fontes de ${ }^{137}$ Césio e ${ }^{133}$ Bário confeccionadas}

A Figura 34, nos mostra as fontes radioativas de ${ }^{137} \mathrm{Cs}$ e ${ }^{133} \mathrm{Ba}$ seladas com resina epóxi que foram confeccionadas.

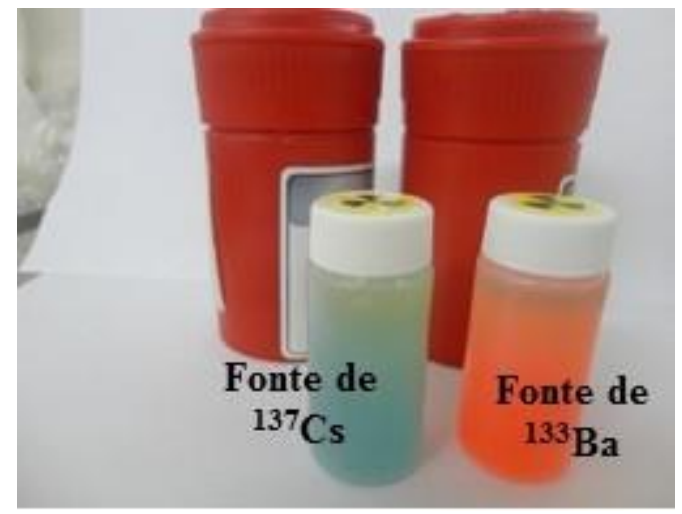

Figura 34 - Fonte de ${ }^{137} \mathrm{Cs}$ e fonte de ${ }^{133} \mathrm{Ba}$ confeccionadas

Os dados da média dos valores das medições obtidas nos três detectores do fabricante Capintec, estão representados na Tabela 8. 
TABELA 8- Medida das atividades das fontes em 3 modelos de detectores Capintec

\begin{tabular}{|c|c|c|c|c|}
\hline $\begin{array}{c}\text { Fonte } \\
\text { Produzidas }\end{array}$ & $\begin{array}{c}\text { Aividade } \\
\text { medida } \\
\text { (MBq) } \\
\text { Detector 15R }\end{array}$ & $\begin{array}{c}\text { Aividade } \\
\text { medida }(\mathrm{MBq}) \\
\text { Detector } 15 \mathrm{~W}\end{array}$ & $\begin{array}{l}\text { Aividade medida } \\
\text { (MBq) } \\
\text { Detector 15BT }\end{array}$ & $\begin{array}{c}\text { Média das } \\
\text { atividades } \\
\text { medidas nos } \\
\text { três detectores }\end{array}$ \\
\hline${ }^{133} \mathbf{B a}$ & 8,91 & 8,91 & 8,85 & 8,89 \\
\hline${ }^{137} \mathrm{Cs}$ & 7,86 & 7,86 & 7,82 & 7,85 \\
\hline
\end{tabular}

Os resultados obtidos nos três detectores são bastante significativos, apresentando valores bem próximos.

\subsection{Resultados do Teste de Estanqueidade}

\subsubsection{Teste de esfregaço}

As fontes são consideradas estanques, pois os valores medidos de atividade estão muito abaixo do que o exigido pela norma ISO 9978, na qual o valor máximo de atividade permitida no papel utilizado após o esfregaço não exceda $185 \mathrm{~Bq}(5 \mathrm{nCi})^{(32)}$.

Utilizando o detector de iodeto de sódio do Capintec CRC-15W, verificamos que os valores medidos de atividade estão muito abaixo do que o exigido pela norma ISO 9978.

Sendo assim, as fontes são consideradas estanques. Os valores das medidas estão representados na Tabela 9. 
Tabela 9 - Medida da atividade do papel utilizado no esfregaço das fontes.

\begin{tabular}{|c|c|c|}
\hline Fontes & $\begin{array}{c}\text { Atividade (Bq) } \\
\text { Antes-Esfregaço }\end{array}$ & $\begin{array}{c}\text { Atividade (Bq) } \\
\text { Depois-Esfregaço }\end{array}$ \\
\hline${ }^{133} \mathrm{Ba}$ & $3,555 \pm 3,056$ & $6,455 \pm 3,008$ \\
\hline${ }^{137} \mathrm{Cs}$ & $5,550 \pm 5,032$ & $11,988 \pm 4,958$ \\
\hline
\end{tabular}

\subsubsection{Testes de imersão à temperatura ambiente e teste de imersão a líquido quente} à $70^{\circ} \mathrm{C}$

Nas Tabelas 10 e 11 são mostrados os resultados da medida de atividade da água destilada antes e depois dos testes de imersão à temperatura ambiente e à temperatura de $70^{\circ} \mathrm{C}$.

Tabela 10 - Medidas da Atividade da água à temperatura ambiente, antes e após a imersão das fontes.

\begin{tabular}{|c|cc|}
\hline Fontes & \multicolumn{2}{|c|}{ Atividade Medida (Bq) } \\
& $\begin{array}{c}\text { Imersão à Temperatura Ambiente(Água) } \\
\text { Antes }\end{array}$ & Depois \\
\hline${ }^{\mathbf{1 3 3}} \mathbf{B a}$ & $0,222 \pm 5,106$ & $5,994 \pm 5,180$ \\
\hline${ }^{\mathbf{1 3 7}} \mathbf{C s}$ & $0,897 \pm 5,042$ & $4,218 \pm 5,069$ \\
\hline
\end{tabular}

Tabela 11- Medidas da Atividade da água à $70^{\circ} \mathrm{C}$, antes e após a imersão das fontes

\begin{tabular}{|c|c|c|}
\hline \multirow[t]{2}{*}{ Fontes } & \multicolumn{2}{|c|}{$\begin{array}{l}\text { Atividade Medida (Bq) } \\
\text { Imersão à } 70 \text { C (Água) }\end{array}$} \\
\hline & Antes & Depois \\
\hline${ }^{133} \mathrm{Ba}$ & $2,627 \pm 5,069$ & $7,770 \pm 2,012$ \\
\hline${ }^{137} \mathrm{Cs}$ & $1,480 \pm 5,065$ & $2,294 \pm 4,069$ \\
\hline
\end{tabular}


Utilizando o detector de iodeto de sódio do Capintec CRC-15W, verificamos que os valores medidos de atividade estão muito abaixo do que o exigido pela norma ISO 9978, na qual o valor máximo de atividade permitida na água utilizada após a imersão não exceda $185 \mathrm{~Bq}(5 \mathrm{nCi}){ }^{(32)}$.

Nos testes de estanqueidade, verificou-se que as fontes são estanques, comprovando a eficiência da resina epóxi como material para selar o material radioativo.

\section{CONCLUSÕES}

A escolha correta do tipo de resina epóxi foi de extrema importância para a confecção das fontes de calibração, a primeira formulação SQ2001 não foi escolhida, pois o endurecedor era mais reativo, sendo inviável para produção de fontes radioativas.

Os testes de exatidão e precisão, realizados nos medidores de atividade, mostram que as medidas realizadas estão dentro do esperado.

Analisando capacidade de cura ambiente da resina com adição de água, conclui-se que a cura ocorreu no tempo de $24 \mathrm{~h}$ à 48 h dependendo da quantidade de solução aquosa, desde que essa quantidade não ultrapasse $20 \%$.

Nos testes de tração e compressão, verificou-se a diminuição da resistência do material frente a adição de água na composição, porém para aplicação na fabricação de fontes de verificação, o máximo que se usa é de 5\% de solução radioativa, apresentando valores de forças tensão e compressão ainda elevados.

Em ambos os testes, verificou-se elevada resistência da resina à tração e à compressão, sendo que para a resina pura à resistência à compressão atingiu valores superiores a $50 \mathrm{MPa}$ (o valor que interessa, pois o máximo que se usa de solução radioativa para produção dessas fontes é de $5 \%$ ).

Analisando a cura da resina por irradiação, verificou-se melhoria nas propriedades mecânicas até por volta de $33 \mathrm{kGy}$. Sendo assim, para acelerar o processo de cura das fontes produzidas poderia utilizar essa dose, ocorrendo a cura da resina em questões de horas e não em dias, tendo uma maior produção. 
A análise da densidade das amostras irradiadas utilizados no teste evidenciou que água (adicionada a composição da matriz epóxi é totalmente incorporada a estrutura do polímero) já que não se verificou qualquer alteração significativa de sua densidade durante a irradiação.

$\mathrm{Na}$ análise termogravimétrica, verificou-se também que a água adicionada advinda da solução ácida está ligada quimicamente à estrutura e não é liberada inicialmente, comparando as formulações soluções ácidas com a resina sem a adição de água, a perda de massa inicial é constante. A temperatura na qual ela começa a decomposição é 300 ${ }^{\circ} \mathrm{C}$, bem elevada. As fontes de calibração, em condições normais não atingirão essa temperatura, pois se encontram estocadas em temperatura ambiente ou ambiente refrigerado.

Nos testes de estanqueidade, verificou-se que as fontes são estanques, comprovando a eficiência da resina epóxi como material para selar o material radioativo.

Analisando todos esses fatores, as fontes seladas podem ser confeccionadas em matriz epóxi DGEBA e catalizador poliamínico DETA modificado, desde que a quantidade de material radioativo, na forma de solução ácida, adicionado à composição não ultrapasse um teor de $20 \%$.

A cura da resina epóxi pode ser melhorada em relação a ambiente, com uso da irradiação desde que seja exposta a uma dose ao redor de 33 kGy durante a cura. 


\section{REFERÊNCIAS BIBLIOGRÁFICAS}

1. COSTA, A.M. Métodos de Calibração e de Intercomparação de Calibradores de Dose Utilizados em Serviços de Medicina Nuclear.1999. (Dissertação) Mestrado. Instituto de Pesquisas Energéticas e Nucleares, São Paulo.

2. REGIS, R. Radiofármaco reverte imagem negativa da energia nuclear. Scientific American Brasil. Edição 5, out. 2002.

3. GAUGLITZ, E. Estudo e levantamento de parâmetros para montagem de um laboratório de produção de fontes radioativas utilizadas na verificação de equipamentos. 2010. Dissertação (Mestrado). Instituto de Pesquisas Energéticas e Nucleares, São Paulo.

4. COMISSÃO NACIONAL DE ENERGIA NUCLEAR. Entidades autorizadas e registradas, medicina nuclear. Disponível em: <http://www.cnen.gov.br/seguranca/consent-prof/entidades-aut-cert.asp>. Acesso em: 20 dez. 2014.

5. ORVIS, A.L. Assay of radiopharmaceuticals.In: HINE, G.J.; SORENSON, J. A. Instrumentation in nuclear medicine. New York, N.Y.: Academic, 1974. v.2, p.459483.

6. HARE, D.L.; HENDEE, W.R.; WHITNEY, W.P.; CHANEY, E.L. Accuracy of well ionization chambre isótopo calibrators. J. Nucl. Med. V.15, n.12, p.1138-1141, 1974.

7. MARTÍ-CLIMENT, J.M., PEÑUELAS, I.; GARCIA-VELlOSO, M.J.; CATAlÁN, R.; CHALEZQUER, A.; CIORDIA, M.A. Control de calidad em calibradores de dossi. VI Congresso de la sociedade española de protección radiológica, 24-27 Septiembre,1996, Córdoba. Radioproteccion. p. 304-305, 1996.

8. SINCLAIR, W.K.; NEWBERY, S.P. A direct Reading meter for measurement of highly active samples of gamma-emiting radioisotopes. J. Sci. Instr. v. 28, p. 234-236, 1951.

9. BULLEN, M. A. Ionization -chamber device for clinical gamma-ray use. Nucleonics, v.11, n. 12, p. 15-17, 1953 
10. SINCLAIR, W.K.; TROTT, N.G.; BELCHER, E.H. The measurement of radioactive samples for clinical use. Brit. J. Rad. v. 27, p. 565-574, 1954

11. HEYDORN, K.Geometrical effects on the rersponse of the National Physical Laboratory ionization chambre type $1383^{\text {a }}$. Int. J. Appl. Radiat. Isot. v. 18, p479-483, 1967.

12. BALDOCK, C.; BATCHELOR S. Analisys of sample volume dependence of 125I in a radionuclide calibrator. Nucl. Med. Commun. v.12, p. 445-450, 1991.

13. JOHNSTON, A.S.; COLOMBETTI, L.G.; BAKER, S.I.; PINSKY, S.M. Dose calibrator readings due to radionuclidic impurities found in radiopharmaceuticals. $\mathbf{N u c l}$. Med. v. 19, n. 1, p. 1-6, 1980.

14. PARAS, P.; HAMILTON, D.R.; EVANS, C.; HERRERA, N.E.; LAGUNASSOLAR, M.C. Iodine-123 assay using a radionuclide calibrator. Int. J. Nucl. Med. Biol. v. 10, n. $2 / 3$, p.111-115,1983

15. KOTZ, C. J.; TREICHEL Jr, P. M. Química Geral e Reações. São Paulo, SP.Thomson, 2005

16. ANTONIO, P. L. Estudo comparativo entre métodos de calibração de aplicadores clínicos de radiação beta. 2009. Dissertação (Mestrado) - Instituto de Pesquisas Energéticas e Nucleares, São Paulo.

17. ONU. Organização das Nações Unidas. Agência Internacional de Pesquisa em Câncer. Apresenta gráficos e tabelas sobre a incidência de câncer. Disponível em: <http://globocan.iarc.fr/Pages/fact_sheets_population.aspx> Acesso em: 15 maio. 2015.

18. MOSTAFA, M.; El-AMIR, M.A. Preparation of ${ }^{137} \mathrm{Cs}$ and ${ }^{60} \mathrm{Co}$ seled sources based on inorganic sorbents for radiometric calibration purposes. Colloids and Sufaces A: Physicochemical na Engineering Aspects,v. 317, p.687-693, 2008.

19. ROSTELATO, M. E. C. M. Estudo e desenvolvimento de uma nova metodologiapara confecção de sementes de iodo-125 para aplicação em braquiterapia. 2006.Tese (Doutorado) - Instituto de Pesquisas Energéticas e Nucleares, São Paulo. 
20. SOUZA, C. D. Comparação entre métodos de fixação do iodo radioativo emsubstrato de prata para confecção de fontes utilizadas em braquiterapia. 2012. Dissertação (Mestrado) - Instituto de Pesquisas Energéticas e Nucleares, São Paulo.

21. IAEA. Agência Internacional de Energia Atômica. Sealed radioactive sources information, resources and advice for key groups about preventing loss of controlover sealed radioactive sources. Disponível em:

$<$ https://www.iaea.org/sites/default/files/sealedradsource1013.pdf>. Acesso em: 10 mar. 2015

22. SAXENA, S. K.; KUMAR, Y.; PANDLEY, U.; SHINDE, S. N.; MUTHE, K. P.; VENKATESH, M.; ASHUTOSH, D. A facile, viable approachtoward the preparation of ${ }^{32} \mathrm{P}$ patches for the treatment of skin cancer. Cancer Biotherapy and Radiopharmaceuticals. v. 26, n. 5, p. 665-670, 2011.

23. CNEN. Comissão Nacional de Energia Nuclear. Requisitos de Radioproteção $\boldsymbol{e}$ Segurança para Serviços de Radioterapia. Março, 1990. (CNEN-NE-3.05).

24. CNEN. Comissão Nacional de Energia Nuclear. Requisitos de Radioproteção e Segurança para Serviços de Radioterapia. Dez, 2013. (CNEN-NE-3.05/2013, Resolução 159/13).

25. FERREIRA, R. J. Desenvolvimento de metodologia para a caracterização de fontes radioativas seladas. 2010. (Dissertação) Mestrado. Instituto de Pesquisas Energéticas e Nucleares, São Paulo.

26. SHTROMBAKH, Y.I.; PLATONOV, P. A.; LOBANOV, N.S.; CHUGUNOV, O.K.; ALEKSANDROV, V.P.; ZINOV'EV, O. A. Epoxy Compounds for Immobilizing Radioactive Wastes. Atomic Energy. v. 98, n. 5, p. 331-333, 2005.

27. YAMAZAKI, I.M.; KOSKINAS, M.F.; DIAS, M.S.; SILVA, L.G.A; VIEIRA, J.M. Optimization of the method for preparing water-equivalent solid sources. In: International Nuclear Atlantic Conference, 2007, Santos. Associação Brasileira de Energia Nuclear.

28. SAHAGAIA, M.; GRIGORESCU, E.L. Water-equivalent solid standard sources. Nucl. Instr. Meth. Phys. Res., v. 312, 1992. p. 236-239. 
29. IAEA. International Atomic Energy Agenc. Quality Control of Nuclear Medicine Instruments. Viena: IAEA, 1991. (IAEA-TECDOC-602).

30. LNHB- Laboratório Nacional Henri Becquerel. Disponível em:< http://www.nucleide.org/DDEP_WG/DDEPdata.htm>. Acesso em: 10 mar. 2014.

31. INTERNATIONAL STANDARD ORGANIZATION. Radiation protection sealed radioactive sources - General requirements and classification. Genebra: ISO, 1992. (ISO 2919).

32. INTERNATIONAL STANDARD ORGANIZATION. Radiation protection sealed radioactive sources - leakage test methods. Genebra: ISO, 1992. (ISO 9978).

33. MAY, C.A., et al. Epoxy Resins Chemistry and Technology.New York USA. 1988

34. MENEZES, G.W. Análise térmica da resina epóxi DGEBA/TETA para formulações diferentes da razão estequiométrica. Revista ABM. São Paulo, v. I, p. 1216, 2004.

35. HATTENHAUER, I. Influência do alinhamento de nanotubos de carbono nas propriedades elétricas de nanocompósitos de matriz epoxídica. 2012. Dissertação (Mestrado). UESC-CCT. SC

36. BIAGINI, A. B.; MARCON, T. G.; SCHMIDT, T. M.; AMICO, S. C.; M. M. C. Anais do $17^{\circ}$ Congresso Brasileiro de Engenharia e Ciências dos Materiais, Foz do Iguaçu, PR, 2006.

37. MENEZES, G.W. Influência do tempo e da temperatura de cura sobre o comportamento mecânico à tração de um sistema epóxi com diferentes razões resina/endurecedor. 1999. Dissertação (Mestrado) em Engenharia e Ciências dos Materiais, Universidade do Norte Fluminense, RJ

38. ANDRADE, W. Uso da Radiação Ionizante em Polímeros. 2011. (Dissertação) Mestrado. Instituto de Pesquisas Energéticas e Nucleares, São Paulo. 
39. NEVES, J.C.; SILVA, G.G.; MENDES, M.W.D.; BRESSIANI, A.H.; BRESSIANI, J.C.; GARCIA, F.G. Efeito da Irradiação Gama nas Propriedades Mecânicas e Térmicas de Redes DGEBA/Amina Cicloalifática com Potencial para Aplicações Médicas. Polímeros. São Carlos, v. 23, p. 814-822, 2013.

40. MAY, C.A.; TANAKA, Y. Epoxy Resins. New York, NY. Marcel Dekker, 1973.

41. MOURA, J.A. Estudo e Desenvolvimento de Metodologia para Controle de Qualidade em Processo de Produção de Fontes Seladas de Iodo-125 para Aplicação em Braquiterapia.2009. Dissertação (Mestrado). IPEN - USP. São Paulo.

42. YAMAZAKI, M.I.; KOSKINAS, F.M.; ANDRADE E SILVA, G. L.; VIEIRA, M.J.; DIAS, S.M. "Desenvolvimento de Fontes radioativas sólidas em resina acrilamida". Proceeding of IX Congresso Brasileiro de Física Médica, Rio de Janeiro.CD ROM (2004).

43. MARTINS, E. W. Estudo e Determinação de Fatores de Influência das dimensões dos frascos de radiofármacos utilizados no IPEN para calibração de ativímetros. 2010. Dissertação (Mestrado). IPEN - USP. São Paulo.

44. COSTA, M.A.; CALDAS, E.V.L; Intercomparação e calibração de medidores de atividade utilizados em serviços de Medicina Nuclear. Radiol Bras. v. 36, n. 5, p. 293 297,2003

45. MATTOS, F. R. Estudo e desenvolvimento de uma semente de Irídio-192 para aplicação em câncer oftálmico. 2010. Dissertação (Mestrado) - Instituto de Pesquisas Energéticas e Nucleares, São Paulo.

46. SILAEX QUÍMICA LTDA, Disponível em:

<http://www.silaex.com.br/datasheet/2001e3454.pdf>. Acesso em: 13 mar. 2014

47. SILAEX QUÍMICA LTDA, Disponível em:

<http://www.silaex.com.br/datasheet/2004e3131.pdf>. Acesso em: 13 mar. 2014

48. AMERICAN SOCIETY FOR TESTING AND MATERIALS Standard Test Method For Tensile Properties Of Plastics. 2001. (ASTM D638-03) 
49. CERON, P.L.; EINLOFT, O.M.S.; LIGABUE, A.R. Comportamento Mecânico à Tração da Resina Epóxi DGEBA/ Poliaminoamida e Amina para Diferentes Formulações da Razão Estequiométrica. V Mostra de Pesquisa da Pós-Graduação PUCRS. 2010

50. AMERICAN SOCIETY FOR TESTING AND MATERIALS. Standard Test Method For Compressive Properties Of Rigid Plastics. 2008. (ASTM D695-08).

51. SILAEX QUÍMICA LTDA, Disponível em

<http://www.silaex.com.br/datasheet/8320.pdf >. Acesso em: 13 mar. 2014

52. CANEVAROLO JR. S. - "Técnicas de Caracterização de polímeros", ARTLIBER, SÃO PAULO, 2004. 